\title{
Investigating new consumer behaviour dimensions in grocery retailing: some evidence from Southern Italy
}

\author{
Vincenzo Basile \\ University of Naples Federico II, Italy
}

\section{Keywords}

Consumer behaviour, FMCG, grocery retail, purchase intentions, retailing industry, share of wallet.

\begin{abstract}
The post-modern consumer is an entirely new figure and represent one of the strategic factors in terms of consumer beahaviuor and purchase intentions. The studies on grocery retailing industry is considered constantly a priority in marketing research and in managerial practice. The retailers that operate in grocery retailing, in order to propose an adequate offering system to customers, want to know what drives a consumer to make their daily purchasing and what are the factors that fosters this process. Therefore, the aim of this paper is to investigate the purchasing behaviour and explore the factors of a local context. The research is based on an explorative approach on a sample of consumers residing in Campania Region. The qualitative methodology was administrated in the three following points: 1) first, data was collected through the diary tool; 2) subsequently, were conducted in depth interviews, on the same respondents of the diaries; lastly, 3) a content analysis was carried out on the results of the diaries and interviews. The research partially confirms the evidence emerging from recent studies on Marketing Performance Measurement (MPM) in Fast Moving Consumer Goods (FMCGs) industry, referred to share of wallet's creation. Moreover, offers a new interpretation of the conceptual model on MPM, in the perspective of consumer behaviour. The research methodology is based on the individual's daily observation during his monthly purchasing process, influenced by cultural factors. The first evidences could be useful for grocery ratailing's managers to modify the business model, in the decisions on offering system, in the distribution format and in terms of pricing strategies (that is, HILO and EDLP strategy). Therefore, the future scenario is of a great interest, both for the evolutionary trends in purchasing behaviour than for the business model's innovations in grocery retailing.
\end{abstract}

Corresponding author: Vincenzo Basile

Email addresses for the corresponding author: vincenzo.basile2@unina.it

First submission received: $3^{\text {rd }}$ May 2019

Revised submission received: 31st July 2019

Accepted: $12^{\text {th }}$ August 2019

\section{Introduction}

This research aims to understand the consumers behaviour in grocery industry. These goods are manufactured and marketed in large quantities and are characterized by a relatively low price. The classic concept of consumer goods coincides with the related domestic expenditure, such as groceries and household chemicals. Recently, we have seen significant changes in the Italian grocery retail structure and retail marketing strategies (Arnold, 1999). Precisely because of all these peculiarities, fast-growing consumer goods characterize the days of all consumers. The figure of the modern consumer has assumed a key role in recent marketing research (Schiffman et al., 2013; Gunter and Furnham, 2014; Solomon and Michael, 2014; East, Singh, Wright and Vanhuele, 2016; Ferreira and Ribeiro, 2017). Understanding consumer behaviour is crucial to analyze the consumption dynamics in the retailing industry. In recent years, grocery retailing has been characterized by considerable evolution and has gained increasing importance in the process of consumer's value creating. The transformation of the modern distribution system and its affirmation as an increasingly active player in competitive scenarios, has had significant effects on how to manage the marketing activity. The importance of retail marketing (McGoldrick, 2002) school encompasses all the actions carried out by modern distribution companies to obtain preference from customers in terms of share of wallet (Mägi, 2003). The marketing research is crucial to discover the potential market and various choices available for the retailer to satisfied new consumer's needs. For this reason, the psychosocial research on customers is a tool of great potential for creating value, thanks to the 
ability to know the consumer and respond promptly to his needs through the management by using various marketing mix. The strategies in retailing industry have been shaped by the intense competition and struggle over market shares. Grocery retailers operate in mature markets with slow growth opportunities, thus the struggle over market shares is justified. Furthermore, have established distinctive store formats which are differentiated from each other based on several dimensions of offering system (Brown, 1992). The study context is the grocery retailing and its evidence in Southern Italy. The grocery retailers differ, among themselves, both for the offering system than for service's types offered to the customers. This is also true in terms of different types of distribution formats. Therefore, we can determine different business models (e.g. EDLP/HILO) operating in grocery retailing, which aim to respond in time to the new needs of consumers, based on different strategic levers. The academic contributions on store management (Berman and Evans, 1995; Castaldo and Mauri, 2017) have highlighted the importance of the physical place to build a strong customer experience, also in grocery retailing. We can expect that the operating of the retail firms changes according to a cultural context because various social and cultural factors shape the retail structure and strategies. The general objective of this work is to investigate the relationships between consumer purchasing behaviour and retail dynamics in grocery retailing industry. More specifically, considering the results of an empirical survey conducted to support the theoretical arguments presented in this paper, the research aims to:

- contribute on the topic of purchase behaviour in grocery retailing (Sherman et al., 1997) and defining some descriptors of purchase process (Bearden, 1999);

- provides an overview of the various scientific contributions in the literature concerning the purchase intentions and consumer behaviour in grocery retailing

- investigate the determinants that impacts on the consumer behaviour and on its purchasing process in a typical southern context;

- explore the main competitive levers of retail chains (Collins-Dodd and Lindley, 2003) of a specific regional context (Campania region).

\section{Literature review}

The analysis of consumer behaviour and the study of the relationships between the determinants of purchasing processes and those of brand value are critical factors in marketing decisions, especially in hypercompetitive contexts (D'Aveni, 1994) characterized by an intense variety and variability of the demand. The value creation process for customers (Cantone, 1996; Wayland and Cole, 1997; Valdani and Busacca, 2000; Valdani, 2000; Costabile 2001), is a fundamental prerequisite for economic value creation (Guatri, 1991; Copeland and Kotwal., 1996; Bennett Stewart III, 1998; Sicca, 2002), it requires an in-depth knowledge of the consumer behaviour. In this perspective, the studies that analyze consumer behaviour are particularly relevant (Mowen, 1995; Peter \& Olson, 1996; East, 1997; Dalli and Romano, 2003; Solomon, 2004), both those who they look at the brand as a cognitive and fiduciary tool (Aaker 1991, 1996, 2001; Keller, 1993, 2001, 2003; Vicari, 1995; Busacca 2000) which inspires and influences purchasing and consumption behaviour. The consumer behaviour is one of the most studied topics by the researchers (Quester, Neal, Pettigrew, Grimmer, Davis and Hawkins, 2007) and marketers in the past and still being studied. Scholars assert different reasons as to why consumer behaviour has been the matter of many academics and researchers. One of the common views is that understanding consumer behaviour has become a factor that has a direct impact on the overall performance of the businesses (Kotler and Keller, 2012). To develop a theoretical framework for the study of consumer behaviour is helpful to begin by considering the evolution of the field of consumer research and the different paradigms of thought that have influenced the discipline. It's possible to identify a set of dimensions emerged in the literature, which can be used to characterize and differentiate, the various perspectives on consumer research. The consumer buying behaviour is studied as a part of the marketing and its main objective it to learn the way how the individuals, groups or organizations choose, buy use and dispose the goods and the factors such as their previous experience, taste, price and branding on which the consumers base their purchasing decisions (Kotler and Keller, 2012). One of such studies of consumer buying behaviour has been conducted by Acebron and Dopico (2000). The aim of the study was to analyze the impact of previous experience on buying behaviour of fresh foods, particularly mussels. In their studies the authors used structural equation model to identify the relationship between the habits and previous experience on the 
consumer buying decision. Their findings show that personal habits and previous experience on of the consumers have a direct impact on the consumers' purchase decision in the example of purchasing fresh mussels. They also found that the image of the product has a crucial impact on the purchasing decision of the consumer and further recommended that the product image should continuously be improved to encourage the consumers towards purchasing. Another study conducted by Variawa (2010) analyzed the influence of packaging on consumer decision making process for Fast Moving Consumer Goods. Lee (2005) carried out study to learn the five stages of consumer decision making process in the example of China.

The researcher focuses on the facts that affect the consumer decision making process on purchasing imported health food products, demographic effects such as gender, education, income and marital status. The author employed questionnaire method to reach the objectives of the research. Analysis of five stages of consumer decision making process indicate that impact of family members on the consumer decision making process of purchasing imported health food products was significant. The stage model of decision-making process was introduced by the studies of O'brien (1971). Although different researchers offer various tendencies towards the definitions of the stages, all of them have common views as they describe the stages in similar ways. One of the common models of consumer decision making process has been offered by Blackwell, Souza, Taghian, Miniard and Engel (2006). According to him, the five stages of consumer decision making process are followings: problem/need recognition, information search, evaluation of alternatives, purchase decision made and post-purchase evaluation. Each stage is then defined by many researchers varying slightly but leading to a common view about what each stage involves. For example, according to Bruner (1993) first stage, need recognition occurs when an individual recognizes the difference between what they have and what they want/need to have. This view is also supported by Neal and Questel (2006) stating that need recognition occurs due to several factors and circumstances such as personal, professional and lifestyle which in turn lead to formation of idea of purchasing. In the next stage, consumer searches information related to desired product or service (Schiffman and Kanuk, 2007).

Information search process can be internal and external. While internal search refers to the process where consumers rely on their personal experiences and believes, external search involves wide search of information which includes addressing the media and advertising or feedbacks from other people (Rose and Samouel, 2009). Once the relevant information about the product or service is obtained the next stage involves analyzing the alternatives. Kotler and Keller (2005) consider this stage as one of the important stages as the consumer considers all the types and alternatives considering the factors such as size, quality and price. Backhaus, Becker, Beverungen, Frohs, Müller, Weddeling, ... and Steiner (2007) suggested that purchase decision is one of the important stages as this stage refers to occurrence of transaction. In other words, once the consumer recognized the need, searched for relevant information and considered the alternatives he/she makes decision whether to make the decision.

Purchasing decision can further be divided into planned purchase, partially purchase or impulse purchase as stated by Kacen (2002). Finally, post-purchase decision involves experience of the consumer about their purchase. Although the importance of this stage is not highlighted by many authors Neal et al. (2004) argues that this is perhaps one of the most important stages in the consumer decision making process as it directly affects the consumers' purchases of the same product or service from the same supplier in the future. The most noteworthy writers that serve as academic advocates of the Five Stage Model of consumer decision making include Tyagi (2004), Kahle and Close (2006) Blackwell et al. (2006), and others. It is important to note that The Five Stage Model is not the only model related to consumer decision-making, and there are also a range of competing models that include Stimulus-OrganismResponse Model of Decision Making developed by Hebb in 1950's, Prescriptive Cognitive Models, The Theory of Trying (Bagozzi and Warsaw, 1990), Model of Goal and Directed Behaviour (Perugini and Bagozzi, 2001).

\subsection{Factors impacting on consumer behaviour}

It has been established that the consumer buying behaviour is the outcome of the needs and wants of the consumer and they purchase to satisfy these needs and wants. Although it sounds simple and clear, these needs can be various depending on the personal factors such as age, psychology and 
personality. Also, there are some other external factors which are broad and beyond the control of the consumer. Many researches have been carried out by academics and scholars on identifying and analyzing those factors affecting the consumers' buying behaviour and as a result, various types of factors have been identified. These factors have been classified into different types and categories in different ways by different authors. For instance, Wiedermann and Cook (2007) classified them into internal and external factor. On the other hand, Winer (2009) divided them into social, personal and psychological factors. Even though they have been classified into different groups by different authors they are similar in scope and purpose (Rao, 2007). There is a wide range of factors that can affect consumer behaviour in different ways. These factors are divided by Hoyer and Stokburger-Sauer (2012) into four broad categories: situational, personal, social and cultural factors. Situational factors impacting consumer behaviour may include location, environment, timing and even weather conditions (Hoyer et al., 2012). To benefit from situational factors major retailers, attempt to construct environment and situations in stores that motivate perspective customers to make purchase decision. Range of available tools to achieve such an outcome include playing relaxing music in stores, producing refreshing smells in stores and placing bread and milk products in supermarkets towards the opposite end of stores to facilitate movement of customers throughout the store to make additional purchases etc. The temporary nature of situational factors is rightly stressed by Batra and Kazmi (2008). Personal factors, on the other hand, include taste preferences, personal circumstances and related factors. The impact of personal factors on consumer decision-making is usually addressed by businesses during market segmentation, targeting and positioning practices by grouping individuals based on their personal circumstances along with other criteria, and developing products and services that accommodate these circumstances in the most effective manner. According to Hoyer et al. (2012) social factors that impacting on consumer behaviour arise from the social interactions in the consumer's perspective. Targeting to opinion leaders usually proves effective strategy when marketing products and services due to influence power in changing behaviour of consumers. Lastly, cultural factors affecting consumer behaviour are related to cross-cultural differences among consumers on local and global scales. Culture can be defined as "the ideas, customs, and social behaviour of a particular people or society" (Oxford Dictionaries, 2015) and the tendency of globalization has made it compulsory for the cross-cultural differences of consumers to be considered when formulating and communicating marketing messages.

Tab. 1: Evolution of studies on consumer behaviour and purchase intentions

\begin{tabular}{|c|c|c|c|c|}
\hline Author & Journal & Topic & Methodology & Findings \\
\hline Bayton, 1958 & $\begin{array}{l}\text { The Journal } \\
\text { of } \\
\text { Marketing, } \\
282-289\end{array}$ & $\begin{array}{l}\text { Motivation, } \\
\text { cognition, learning: } \\
\text { Basic factors in } \\
\text { consumer } \\
\text { behaviour }\end{array}$ & $\begin{array}{l}\text { Qualitative/ } \\
\text { theoretical } \\
\text { paper }\end{array}$ & $\begin{array}{l}\text { "Human behaviour can be grouped into three } \\
\text { categories: motivation, cognition, and } \\
\text { learning" }\end{array}$ \\
\hline $\begin{array}{l}\text { Venkatesan, } \\
1966\end{array}$ & $\begin{array}{l}\text { Journal of } \\
\text { Marketing } \\
\text { Research, } \\
384-387\end{array}$ & $\begin{array}{l}\text { Experimental study } \\
\text { of consumer } \\
\text { behaviour } \\
\text { conformity and } \\
\text { independence }\end{array}$ & $\begin{array}{l}\text { Quantitative } \\
\text { / statistical } \\
\text { surveys }\end{array}$ & $\begin{array}{l}\text { "The acceptance of social influence implies that } \\
\text { consumers accept information provided by } \\
\text { their peer groups on the quality of a product, } \\
\text { which is hard to evaluate objectively" }\end{array}$ \\
\hline $\begin{array}{l}\text { Sheth and } \\
\text { Venkatesan, } \\
1968\end{array}$ & $\begin{array}{l}\text { Journal of } \\
\text { Marketing } \\
\text { Research, } \\
307-310\end{array}$ & $\begin{array}{l}\text { Risk-reduction } \\
\text { processes in } \\
\text { repetitive consumer } \\
\text { behaviour }\end{array}$ & $\begin{array}{l}\text { Quantitative } \\
\text { / statistical } \\
\text { methods }\end{array}$ & $\begin{array}{l}\text { "The consumers may seek information from } \\
\text { personal and impersonal sources when there } \\
\text { is no experience. Such active information } \\
\text { seeking may continue only if uncertainty } \\
\text { persists. Similarly, active information seeking } \\
\text { may only be important when either the buyer } \\
\text { moves into a new product class or the product } \\
\text { is an innovation" }\end{array}$ \\
\hline
\end{tabular}




\begin{tabular}{|c|c|c|c|c|}
\hline Taylor, 1974 & $\begin{array}{l}\text { The Journal } \\
\text { of } \\
\text { Marketing, } \\
54-60\end{array}$ & $\begin{array}{l}\text { The role of risk in } \\
\text { consumer } \\
\text { behaviour }\end{array}$ & $\begin{array}{l}\text { Qualitative/ } \\
\text { theoretical } \\
\text { paper }\end{array}$ & $\begin{array}{l}\text { "Product warranties, or insurance } \\
\text { policieswould be a likely marketing program... } \\
\text { In each of these instances, it should be } \\
\text { possible to compare the cost/effectiveness of } \\
\text { the suggested programs against alternative } \\
\text { programs designed for different groups and in } \\
\text { response to different perceptions of risk" }\end{array}$ \\
\hline Belk, 1975 & $\begin{array}{l}\text { Journal of } \\
\text { Consumer } \\
\text { research, } \\
2(3), 157-164\end{array}$ & $\begin{array}{l}\text { Situational variables } \\
\text { and consumer } \\
\text { behaviour }\end{array}$ & $\begin{array}{l}\text { Quantitative } \\
\text { / statistical } \\
\text { surveys }\end{array}$ & $\begin{array}{l}\text { "The situational influence is a pervasive } \\
\text { factor in consumer behaviour" }\end{array}$ \\
\hline $\begin{array}{l}\text { Cummings } \\
\text { and } \\
\text { Venkatesan, } \\
1976\end{array}$ & $\begin{array}{l}\text { Journal of } \\
\text { Marketing } \\
\text { Research, } \\
\text { 303-308 }\end{array}$ & $\begin{array}{l}\text { Cognitive } \\
\text { dissonance and } \\
\text { consumer } \\
\text { behaviour }\end{array}$ & $\begin{array}{l}\text { Qualitative/ } \\
\text { conceptual } \\
\text { paper }\end{array}$ & $\begin{array}{l}\text { "The evidence to date on the application of } \\
\text { dissonance theory to consumer behaviour is } \\
\text { "not proven" }\end{array}$ \\
\hline Morrison, 1979 & $\begin{array}{l}\text { The Journal } \\
\text { of } \\
\text { Marketing, } \\
65-74\end{array}$ & $\begin{array}{l}\text { Purchase intentions } \\
\text { and purchase } \\
\text { behaviour }\end{array}$ & $\begin{array}{l}\text { Quantitative } \\
\text { / statistical } \\
\text { methods }\end{array}$ & $\begin{array}{l}\text { "At the moment there is not an adequate set } \\
\text { of purchase intentions with follow up } \\
\text { purchase behaviour } \\
\text { studies in the literature to make the above } \\
\text { type of forecast" }\end{array}$ \\
\hline Levy, 1981 & $\begin{array}{l}\text { The Journal } \\
\text { of } \\
\text { Marketing, } \\
49-61\end{array}$ & $\begin{array}{l}\text { Interpreting } \\
\text { consumer } \\
\text { mythology: a } \\
\text { structural approach } \\
\text { to consumer } \\
\text { behaviour }\end{array}$ & $\begin{array}{l}\text { Qualitative/ } \\
\text { conceptual } \\
\text { paper }\end{array}$ & $\begin{array}{l}\text { "Consumer behaviour in the food area uses } \\
\text { fundamental generalizations about the } \\
\text { meanings of products in a broadly } \\
\text { conventional way, within which dynamic } \\
\text { processes of individuation and differentiation } \\
\text { go on" }\end{array}$ \\
\hline Sirgy, 1982 & $\begin{array}{l}\text { Journal of } \\
\text { consumer } \\
\text { research, } \\
9(3), 287-300\end{array}$ & $\begin{array}{l}\text { Self-concept in } \\
\text { consumer } \\
\text { behaviour }\end{array}$ & $\begin{array}{l}\text { Quantitative } \\
\text { / statistical } \\
\text { surveys }\end{array}$ & $\begin{array}{l}\text { "Knowledge generated from self-concept } \\
\text { research can also contribute to consumer } \\
\text { attitude modeling and consumer decision- } \\
\text { making research" }\end{array}$ \\
\hline Gardner, 1985 & $\begin{array}{l}\text { Journal of } \\
\text { Consumer } \\
\text { research, } \\
12(3), 281- \\
300\end{array}$ & $\begin{array}{l}\text { Mood states and } \\
\text { consumer } \\
\text { behaviour }\end{array}$ & $\begin{array}{l}\text { Qualitative/ } \\
\text { conceptual } \\
\text { paper }\end{array}$ & $\begin{array}{l}\text { "The effects of mood states at the point-of- } \\
\text { purchase may be substantial and potentially } \\
\text { important for marketing action, but research } \\
\text { is needed to investigate the strength of mood } \\
\text { effects" }\end{array}$ \\
\hline Rook, 1985 & $\begin{array}{l}\text { Journal of } \\
\text { Consumer } \\
\text { Research, } \\
12(3), 251- \\
264\end{array}$ & $\begin{array}{l}\text { The ritual } \\
\text { dimension of } \\
\text { consumer } \\
\text { behaviour }\end{array}$ & $\begin{array}{l}\text { Qualitative/ } \\
\text { conceptual } \\
\text { paper }\end{array}$ & $\begin{array}{l}\text { "To study consumers' ritual behaviours } \\
\text { challenges the research community to try } \\
\text { more holistic, qualitative approaches. By its } \\
\text { very nature much ritual behaviour invites } \\
\text { field observation" }\end{array}$ \\
\hline $\begin{array}{l}\text { Havlena and } \\
\text { Holbrook, } \\
1986\end{array}$ & $\begin{array}{l}\text { Journal of } \\
\text { consumer } \\
\text { research, } \\
13(3), 394- \\
404\end{array}$ & $\begin{array}{l}\text { The varieties of } \\
\text { consumption } \\
\text { experience: } \\
\text { comparing two } \\
\text { typologies of } \\
\text { emotion in } \\
\text { consumer } \\
\text { behaviour }\end{array}$ & $\begin{array}{l}\text { Qualitative/ } \\
\text { conceptual } \\
\text { paper }\end{array}$ & $\begin{array}{l}\text { "The research reviewed here clearly shows } \\
\text { causal inferences influence a variety of } \\
\text { important consumer responses, as well as } \\
\text { those whose actions impinge on consumers, } \\
\text { such as salespersons" }\end{array}$ \\
\hline $\begin{array}{l}\text { Park, Iyer and } \\
\text { Smith, } 1989\end{array}$ & $\begin{array}{l}\text { Journal of } \\
\text { consumer } \\
\text { research, } \\
15(4), 422- \\
433\end{array}$ & $\begin{array}{l}\text { The effects of } \\
\text { situational factors } \\
\text { on in-store grocery } \\
\text { shopping } \\
\text { behaviour: The role } \\
\text { of store } \\
\text { environment and } \\
\text { time available for } \\
\text { shopping }\end{array}$ & $\begin{array}{l}\text { Qualitative/ } \\
\text { conceptual } \\
\text { paper }\end{array}$ & $\begin{array}{l}\text { "Two factors have an impact on such } \\
\text { shopping behaviours as failure to make the } \\
\text { intended purchases, unplanned buying, } \\
\text { brand and product class switching, and } \\
\text { purchase volume deliberation" }\end{array}$ \\
\hline
\end{tabular}




\begin{tabular}{|c|c|c|c|c|}
\hline $\begin{array}{l}\text { Day, Gan, } \\
\text { Gendall, and } \\
\text { Esslemont, } \\
1991\end{array}$ & $\begin{array}{l}\text { Marketing } \\
\text { Bulletin, } \\
2(5), 18-30\end{array}$ & $\begin{array}{l}\text { Predicting purchase } \\
\text { behaviour }\end{array}$ & $\begin{array}{l}\text { Quantitative } \\
\text { / statistical } \\
\text { surveys }\end{array}$ & $\begin{array}{l}\text { "The Scale has been shown to be a better } \\
\text { predictor of consumer purchases than buying } \\
\text { intentions scales, and it can be successfully } \\
\text { used in both face-to-face and self-completion } \\
\text { surveys and for forecasting periods ranging } \\
\text { from three months to a year" }\end{array}$ \\
\hline $\begin{array}{l}\text { Haugtvedt, } \\
1992\end{array}$ & $\begin{array}{l}\text { Journal of } \\
\text { Consumer } \\
\text { Psychology, } \\
1(3), 239-260\end{array}$ & $\begin{array}{l}\text { Need for cognition } \\
\text { and advertising: } \\
\text { Understanding the } \\
\text { role of personality } \\
\text { variables in } \\
\text { consumer } \\
\text { behaviour }\end{array}$ & $\begin{array}{l}\text { Quantitative } \\
\text { / statistical } \\
\text { surveys }\end{array}$ & $\begin{array}{l}\text { "Interestingly, results of a binomial logit } \\
\text { analysis suggest that heavier users of coupons } \\
\text { are significantly more likely to redeem a } \\
\text { coupon that is about to expire and to be } \\
\text { bothered by allowing a coupon to expire } \\
\text { unused. Thus, it is likely that heavy coupon } \\
\text { users can be instrumental in the observed } \\
\text { increase in redemption rates near the } \\
\text { expiration date" }\end{array}$ \\
\hline $\begin{array}{l}\text { Chang and } \\
\text { Wildt, } 1994\end{array}$ & $\begin{array}{l}\text { Journal of } \\
\text { the } \\
\text { Academy of } \\
\text { Marketing } \\
\text { science, } \\
22(1), 16-27\end{array}$ & $\begin{array}{l}\text { Price, product } \\
\text { information, and } \\
\text { purchase intention: } \\
\text { An empirical study }\end{array}$ & $\begin{array}{l}\text { Quantitative } \\
\text { / statistical } \\
\text { surveys }\end{array}$ & $\begin{array}{l}\text { "Perceived quality and perceived price } \\
\text { contribute to the formation of value } \\
\text { perceptions and purchase intentions" }\end{array}$ \\
\hline Herche, 1994 & $\begin{array}{l}\text { International } \\
\text { Marketing } \\
\text { Review, } \\
11(3), 4-16\end{array}$ & $\begin{array}{l}\text { Ethnocentric } \\
\text { tendencies, } \\
\text { marketing strategy } \\
\text { and import } \\
\text { purchase behaviour }\end{array}$ & $\begin{array}{l}\text { Qualitative/ } \\
\text { conceptual } \\
\text { paper }\end{array}$ & $\begin{array}{l}\text { "Ethnocentric tendencies are able to explain a } \\
\text { much greater amount of variation in purchase } \\
\text { behaviour than marketing mix variables" }\end{array}$ \\
\hline $\begin{array}{l}\text { Donovan, } \\
\text { Rossiter, } \\
\text { Marcoolyn } \\
\text { and Nesdale, } \\
1994\end{array}$ & $\begin{array}{l}\text { Journal of } \\
\text { retailing, } \\
70(3), 283- \\
294\end{array}$ & $\begin{array}{l}\text { Store atmosphere } \\
\text { and purchasing } \\
\text { behaviour }\end{array}$ & $\begin{array}{l}\text { Quantitative } \\
\text { / statistical } \\
\text { methods }\end{array}$ & $\begin{array}{l}\text { "The practical significance for retailers is that } \\
\text { emotional responses induced by the store } \\
\text { environment can affect the time and money } \\
\text { that consumers spend in the store" }\end{array}$ \\
\hline Omar, 1996 & $\begin{array}{l}\text { Service } \\
\text { Industries } \\
\text { Journal, } \\
16(1), 58-66\end{array}$ & $\begin{array}{l}\text { Grocery purchase } \\
\text { behaviour for } \\
\text { national and own- } \\
\text { label brands }\end{array}$ & $\begin{array}{l}\text { Quantitative } \\
\text { / statistical } \\
\text { methods }\end{array}$ & $\begin{array}{l}\text { "These grocery shoppers differ in terms of } \\
\text { socio-economic status, personal } \\
\text { characteristics and shopping behaviour. The } \\
\text { findings provide information useful to both } \\
\text { retailing and manufacturing interests as } \\
\text { retail marketing strategies are developed in } \\
\text { the face of intensifying competition for } \\
\text { shoppers' food expenditure in the market- } \\
\text { place" }\end{array}$ \\
\hline $\begin{array}{l}\text { Sherman, } \\
\text { Mathur and } \\
\text { Smith, } 1997\end{array}$ & $\begin{array}{l}\text { Psychology } \\
\text { and } \\
\text { Marketing, } \\
\text { 14(4), 361- } \\
378\end{array}$ & $\begin{array}{l}\text { Store environment } \\
\text { and consumer } \\
\text { purchase } \\
\text { behaviour: } \\
\text { mediating role of } \\
\text { consumer emotions }\end{array}$ & $\begin{array}{l}\text { Quantitative } \\
\text { / statistical } \\
\text { methods }\end{array}$ & $\begin{array}{l}\text { "The consumer's emotional state may affect } \\
\text { his or her shopping behaviour after the } \\
\text { decision to shop has been made. At the point } \\
\text { of purchase there are many ways to make a } \\
\text { customer feel better: suitable layout, } \\
\text { cleanliness, colors, and salesperson training" }\end{array}$ \\
\hline $\begin{array}{l}\text { Follows and } \\
\text { Jobber, } 2000\end{array}$ & $\begin{array}{l}\text { European } \\
\text { journal of } \\
\text { Marketing, } \\
34(5 / 6), 723- \\
746\end{array}$ & $\begin{array}{l}\text { Environmentally } \\
\text { responsible } \\
\text { purchase } \\
\text { behaviour: a test of } \\
\text { a consumer model }\end{array}$ & $\begin{array}{l}\text { Quantitative } \\
\text { / statistical } \\
\text { methods }\end{array}$ & $\begin{array}{l}\text { "Individual consequences, which take the } \\
\text { personal implications of consumption into } \\
\text { account, were found to be just as important } \\
\text { in predicting intention as the environmental } \\
\text { consequences of a product" }\end{array}$ \\
\hline $\begin{array}{l}\text { Kim, Forsythe, } \\
\text { Gu and Jae } \\
\text { Moon, } 2002\end{array}$ & $\begin{array}{l}\text { Journal of } \\
\text { Consumer } \\
\text { marketing, } \\
19(6), 481- \\
502\end{array}$ & $\begin{array}{l}\text { Cross-cultural } \\
\text { consumer values } \\
\text { need and purchase } \\
\text { behaviour }\end{array}$ & $\begin{array}{l}\text { Quantitative } \\
\text { / statistical } \\
\text { methods }\end{array}$ & $\begin{array}{l}\text { "Among the three types of needs identified to } \\
\text { be satisfied through apparel experiential } \\
\text { needs were the most important needs that } \\
\text { influenced apparel purchases of female } \\
\text { consumers in both Asian markets. Consumers } \\
\text { in both country markets exhibited brand loyal }\end{array}$ \\
\hline
\end{tabular}




\begin{tabular}{|c|c|c|c|c|}
\hline & & & & $\begin{array}{l}\text { behaviour in apparel purchases, fulfilling all } \\
\text { three needs" }\end{array}$ \\
\hline Jacoby, 2002 & $\begin{array}{l}\text { Journal of } \\
\text { Consumer } \\
\text { Psychology, } \\
12(1), 51-57 .\end{array}$ & $\begin{array}{l}\text { Stimulus-Organism- } \\
\text { Response } \\
\text { Reconsidered: An } \\
\text { Evolutionary Step } \\
\text { in Modeling } \\
\text { (Consumer) } \\
\text { Behaviour }\end{array}$ & $\begin{array}{l}\text { Quantitative } \\
\text { / statistical } \\
\text { methods }\end{array}$ & $\begin{array}{l}\text { "The need to evolve the visual depictions of } \\
\text { our consumer behaviour models is addressed. } \\
\text { Previous models are criticized for being } \\
\text { constructions that fail to build on prior } \\
\text { theory, and lack parsimony, } \\
\text { comprehensiveness, coherence, and flexibility. } \\
\text { More revolutionary movement in consumer } \\
\text { behaviour modelling is encouraged and an } \\
\text { integrative Stimulus-Organism-Response } \\
\text { framework is presented for consideration." }\end{array}$ \\
\hline $\begin{array}{l}\text { Meyer- } \\
\text { Waarden, and } \\
\text { Benavent, } 2006\end{array}$ & $\begin{array}{l}\text { Journal of } \\
\text { Marketing } \\
\text { Management } \\
\text { 22(1-2), 61- } \\
88\end{array}$ & $\begin{array}{l}\text { The impact of } \\
\text { loyalty programmes } \\
\text { on repeat purchase } \\
\text { behaviour }\end{array}$ & $\begin{array}{l}\text { Quantitative } \\
\text { / statistical } \\
\text { methods }\end{array}$ & $\begin{array}{l}\text { "When all companies have loyalty programs, } \\
\text { the market is characterized by an absence of } \\
\text { change of the competitive situation" }\end{array}$ \\
\hline Jaakkola, 2007 & $\begin{array}{l}\text { Marketing } \\
\text { Theory, } 7(1) \text {, } \\
93-108\end{array}$ & $\begin{array}{l}\text { Purchase decision- } \\
\text { making within } \\
\text { professional } \\
\text { consumer services }\end{array}$ & $\begin{array}{l}\text { Qualitative/ } \\
\text { theoretical } \\
\text { paper }\end{array}$ & $\begin{array}{l}\text { "Professional consumer services represent a } \\
\text { unique setting for purchase decision-making } \\
\text { and cannot be considered equivalent to the } \\
\text { organizational or consumer setting" }\end{array}$ \\
\hline $\begin{array}{l}\text { Kim and Lee, } \\
2008\end{array}$ & $\begin{array}{l}\text { International } \\
\text { Journal of } \\
\text { Consumer } \\
\text { Studies, } \\
32(6), 619- \\
627\end{array}$ & $\begin{array}{l}\text { Consumer product } \\
\text { search and } \\
\text { purchase behaviour } \\
\text { using various retail } \\
\text { channels: the role of } \\
\text { perceived retail } \\
\text { usefulness }\end{array}$ & $\begin{array}{l}\text { Quantitative } \\
\text { / statistical } \\
\text { methods }\end{array}$ & $\begin{array}{l}\text { "Consumers who perceived a certain retail } \\
\text { channel more useful for product information } \\
\text { search searched for product information more } \\
\text { frequently via that retail channel and } \\
\text { purchased products more often via that retail } \\
\text { channel. Consumers who were more satisfied } \\
\text { with apparel purchases from a retail channel } \\
\text { purchased the products more frequently via } \\
\text { that retail channel" }\end{array}$ \\
\hline $\begin{array}{l}\text { De Mooij and } \\
\text { Hofstede, } 2011\end{array}$ & $\begin{array}{l}\text { Journal of } \\
\text { International } \\
\text { Consumer } \\
\text { Marketing, } \\
23(3-4), 181- \\
192\end{array}$ & $\begin{array}{l}\text { Cross-cultural } \\
\text { consumer } \\
\text { behaviour }\end{array}$ & $\begin{array}{l}\text { Qualitative/ } \\
\text { theoretical } \\
\text { paper }\end{array}$ & $\begin{array}{l}\text { "An increasing body of knowledge is } \\
\text { available that helps explain differences in } \\
\text { consumer behaviour across culture" }\end{array}$ \\
\hline $\begin{array}{l}\text { Foxall, } \\
\text { Oliveira- } \\
\text { Castro, James } \\
\text { and } \\
\text { Schrezenmaier } \\
, 2011\end{array}$ & $\begin{array}{l}\text { Management } \\
\text { Online } \\
\text { Review }\end{array}$ & $\begin{array}{l}\text { Consumer } \\
\text { behaviour analysis } \\
\text { and the behavioural } \\
\text { perspective model }\end{array}$ & $\begin{array}{l}\text { Qualitative/ } \\
\text { theoretical } \\
\text { paper }\end{array}$ & $\begin{array}{l}\text { "The probability of purchase and } \\
\text { consumption depends on the relative weight } \\
\text { of the reinforcing and aversive consequences } \\
\text { that are signaled by the elements in the } \\
\text { consumer behaviour setting" }\end{array}$ \\
\hline $\begin{array}{l}\text { Paul and } \\
\text { Rana, } 2012\end{array}$ & $\begin{array}{l}\text { Journal of } \\
\text { consumer } \\
\text { Marketing, } \\
29(6), 412- \\
422\end{array}$ & $\begin{array}{l}\text { Consumer } \\
\text { behaviour and } \\
\text { purchase intention } \\
\text { for organic food }\end{array}$ & $\begin{array}{l}\text { Qualitative/ } \\
\text { theoretical } \\
\text { paper }\end{array}$ & $\begin{array}{l}\text { "Consumers in developing countries are keen } \\
\text { to purchase organic food, which is quite } \\
\text { popular in developed countries. The lack of } \\
\text { effective distribution and promotion systems } \\
\text { severely affect the availability of organic food } \\
\text { and at the same time, presents an opportunity } \\
\text { to improve the ease of availability of organic } \\
\text { food" }\end{array}$ \\
\hline
\end{tabular}




\begin{tabular}{|c|c|c|c|c|}
\hline Gajjar, 2013 & $\begin{array}{l}\text { International } \\
\text { Journal of } \\
\text { Research in } \\
\text { Humanities } \\
\text { and Social } \\
\text { Sciences, } \\
1(2), 10-15\end{array}$ & $\begin{array}{l}\text { Factors affecting } \\
\text { consumer } \\
\text { behaviour }\end{array}$ & $\begin{array}{l}\text { Qualitative/ } \\
\text { theoretical } \\
\text { paper }\end{array}$ & $\begin{array}{l}\text { "The study of Consumer Behaviour is quite } \\
\text { complex, because of many variables involved } \\
\text { and their tendency to interact with } \mathcal{E} \\
\text { influence each other. These variables are } \\
\text { divided into the following major sections: } \\
\text { external environmental, culture, and sub- } \\
\text { culture, social class, and social group, family, } \\
\text { and inter-personal influences" }\end{array}$ \\
\hline $\begin{array}{l}\text { Chakrabortty, } \\
\text { Hossain, Azad } \\
\text { and Islam, } \\
2013\end{array}$ & World, 3(4) & $\begin{array}{l}\text { Analysing the } \\
\text { effects of sales } \\
\text { promotion and } \\
\text { advertising on } \\
\text { consumer's } \\
\text { purchase behaviour }\end{array}$ & $\begin{array}{l}\text { Quantitative } \\
\text { / statistical } \\
\text { methods }\end{array}$ & $\begin{array}{l}\text { "This study also suggests to the marketers to } \\
\text { be aware of the new or unknown product, as } \\
\text { sales promotion could have strong negative } \\
\text { effects on consumers' internal price reference } \\
\text { and perceived quality. This work also } \\
\text { highlights the importance of integrating the } \\
\text { advertising with different promotional } \\
\text { activities to improve the growth of sales of a } \\
\text { product" }\end{array}$ \\
\hline $\begin{array}{l}\text { Ahmetoglu, } \\
\text { Furnham and } \\
\text { Fagan, } 2014\end{array}$ & $\begin{array}{l}\text { Journal of } \\
\text { Retailing } \\
\text { and } \\
\text { Consumer } \\
\text { Services, } \\
21(5), 696- \\
707\end{array}$ & $\begin{array}{l}\text { Pricing practices: A } \\
\text { critical review of } \\
\text { their effects on } \\
\text { consumer } \\
\text { perceptions and } \\
\text { behaviour }\end{array}$ & $\begin{array}{l}\text { Qualitative/ } \\
\text { theoretical } \\
\text { paper }\end{array}$ & $\begin{array}{l}\text { "The pure presentation of a price alone that } \\
\text { is, independent from an actual price change } \\
\text { can have a significant impact on consumer } \\
\text { perceptions and behaviours" }\end{array}$ \\
\hline Rani & $\begin{array}{l}\text { International } \\
\text { journal of } \\
\text { current } \\
\text { research and } \\
\text { academic } \\
\text { review, 2(9), } \\
52-61\end{array}$ & $\begin{array}{l}\text { Factors influencing } \\
\text { consumer } \\
\text { behaviour }\end{array}$ & $\begin{array}{l}\text { Qualitative/ } \\
\text { theoretical } \\
\text { paper }\end{array}$ & $\begin{array}{l}\text { "For a successful consumer-oriented market } \\
\text { service provider should work as psychologist } \\
\text { to procure consumers. By keeping in mind } \\
\text { affecting factors things can be made favorable } \\
\text { and goal of consumer satisfaction can be } \\
\text { achieved. Study of } \\
\text { consumer buying behaviour is gate way to } \\
\text { success in market" }\end{array}$ \\
\hline $\begin{array}{l}\text { Zeugner-Roth, } \\
\text { Žabkar and } \\
\text { Diamantopoul } \\
\text { os, } 2015\end{array}$ & $\begin{array}{l}\text { Journal of } \\
\text { international } \\
\text { marketing, } \\
\text { 23(2), 25-54 }\end{array}$ & $\begin{array}{l}\text { Consumer } \\
\text { ethnocentrism, } \\
\text { national identity, } \\
\text { and consumer } \\
\text { cosmopolitanism as } \\
\text { drivers of consumer } \\
\text { behaviour: A social } \\
\text { identity theory } \\
\text { perspective }\end{array}$ & $\begin{array}{l}\text { Quantitative } \\
\text { / statistical } \\
\text { methods }\end{array}$ & $\begin{array}{l}\text { "Several undiscovered patterns regarding the } \\
\text { interplay of consumer ethnocentrism, } \\
\text { national identity and consumer } \\
\text { cosmopolitanism as drivers of consumer } \\
\text { behaviour and offer managerial guidance on } \\
\text { their relevance as segmentation variables" }\end{array}$ \\
\hline Zhang, 2015 & $\begin{array}{l}\text { Open journal } \\
\text { of business } \\
\text { and } \\
\text { management } \\
, 3(1)\end{array}$ & $\begin{array}{l}\text { The impact of brand } \\
\text { image on consumer } \\
\text { behaviour }\end{array}$ & $\begin{array}{l}\text { Qualitative/ } \\
\text { theoretical } \\
\text { paper }\end{array}$ & $\begin{array}{l}\text { "Customer loyalty could be recognized as the } \\
\text { extension of customer satisfaction. Earlier } \\
\text { studies define customer loyalty as repeated } \\
\text { purchasing behaviours in a narrow sense. } \\
\text { Generally, customer loyalty stems from } \\
\text { customers' approval of a brand, which leads } \\
\text { to their continuously purchasing behaviour of } \\
\text { the brand and thus generates profits for the } \\
\text { company" }\end{array}$ \\
\hline Pappas, 2016 & $\begin{array}{l}\text { Journal of } \\
\text { Retailing } \\
\text { and } \\
\text { Consumer } \\
\text { Services, 29, } \\
92-103\end{array}$ & $\begin{array}{l}\text { Marketing } \\
\text { strategies, } \\
\text { perceived risks, and } \\
\text { consumer trust in } \\
\text { online buying } \\
\text { behaviour }\end{array}$ & $\begin{array}{l}\text { Quantitative } \\
\text { / statistical } \\
\text { methods }\end{array}$ & $\begin{array}{l}\text { "The formulation of product and e-channel } \\
\text { related consumer trust, and the extent to } \\
\text { which it is influenced by perceived financial, } \\
\text { performance, security and time loss risks" }\end{array}$ \\
\hline
\end{tabular}




\begin{tabular}{|c|c|c|c|c|}
\hline Stephen, 2016 & $\begin{array}{l}\text { Current } \\
\text { Opinion in } \\
\text { Psychology, } \\
10,17-21\end{array}$ & $\begin{array}{l}\text { The role of digital } \\
\text { and social media } \\
\text { marketing in } \\
\text { consumer } \\
\text { behaviour }\end{array}$ & $\begin{array}{l}\text { Qualitative/ } \\
\text { theoretical } \\
\text { paper }\end{array}$ & $\begin{array}{l}\text { "Five themes are identified in consumer } \\
\text { behaviour on social media marketing: (i) } \\
\text { consumer digital culture, (ii) responses to } \\
\text { digital advertising, (iii) effects of digital } \\
\text { environments on consumer behaviour, (iv) } \\
\text { mobile environments, and (v) online word of } \\
\text { mouth (WOM)" }\end{array}$ \\
\hline $\begin{array}{l}\text { Aschemann- } \\
\text { Witzel, Jensen, } \\
\text { J. H., Jensen, } \\
\text { M. H., and } \\
\text { Kulikovskaja, } \\
2017\end{array}$ & $\begin{array}{l}\text { Appetite, } \\
116,246-258\end{array}$ & $\begin{array}{l}\text { Consumer } \\
\text { behaviour towards } \\
\text { price reduced } \\
\text { suboptimal foods in } \\
\text { the supermarket } \\
\text { and the relation to } \\
\text { food waste in } \\
\text { households }\end{array}$ & $\begin{array}{l}\text { Quantitative } \\
\text { / statistical } \\
\text { methods }\end{array}$ & $\begin{array}{l}\text { "Favorably supporting consumer } \\
\text { consideration in-store, sales of price-reduced } \\
\text { suboptimal foods might be increased, and the } \\
\text { likelihood improved that they are consumed } \\
\text { in the household" }\end{array}$ \\
\hline
\end{tabular}

Source: own elaborations.

\subsection{The antecedents of purchase intentions}

Traditionally, the term intention is defined as the antecedents that stimulate and drive consumers' purchases of products and services (Hawkins and Mothersbaugh, 2010). One of the most common approaches undertaken by marketers in gaining an understanding about consumers' actual behaviour is through studying their intentions (Blackwell et al., 2006; Ghalandari and Norouzi, 2012). Kim and Pysarchik (2000) have demonstrated the existence of a strong correlation between these two respective constructs. Hence, they assert that purchase intention serves as an alternative for measuring consumers' purchase behaviour. Therefore, consumers' intention toward a behaviour has remained the central focus of well-known theories like theory of reasoned action (TRA). This claim is also supported by Azjen (1991) who mention that intention is the factor that motivates consumers and in turn influences their behaviour. It reveals how hard consumers are willing to try, as well as the amount of effort they intend to exert for performing a respective behaviour. According to them, the probability that a behaviour will be performed by individuals largely relies on the strength of their intentions. When the intentions of performing certain behaviour are strong, there are higher likelihoods that the respective behaviour will be performed. Purchase intention or referring to willingness to buy is widely defined as the likelihood of a consumer to purchase a product or service (Dodd and Supa, 2011; Sam and Tahir, 2009). It is also being defined as a conscious plan made by an individual to try to purchase a brand (Spears and Singh, 2004). The concept of purchase intention is rooted in psychological and is extensively used in behavioural studies (Dodd and Supa, 2011). Purchase intention is being characterized as a behavioural tendency that the consumer will purchase the product (Monroe and Krishnan, 1985) and as an important indicator for the actual purchasing decision (Tan, 1999). This statement is then further supported by Li, Davies, Edwards, Kinman and Duan (2002), stated that purchase intention is a common measure that usually employed to assess effectiveness of purchase behaviour. Purchase intention is planning to buy certain goods or services in the future, not necessarily to implement the purchase intention due to it is depends on individual's ability to perform (Warshaw and Davis, 1985 in Qun et al., 2012). According to Blackwell et al. (2001), what is cross in the customers' mind signifies intention to purchase by them. The similar researchers state that consumers will go through the process of recognized the product to purchase, then they will find the information about the product, evaluate, purchase and feedback. Therefore, they will purchase a product after making research in advance so that they will purchase right product that meet with their needs and wants. Ultimately, purchase intention is a kind of decision-making that studies the reason to buy a brand by consumer (Shah et al., 2012). Mirabi, Akbariyeh and Tahmasebifard (2015) define purchase intention as a situation where consumer tends to buy a certain product in certain condition. Customers purchase decision is a complex process.

Purchase intention usually is related to the behaviour, perceptions and attitudes of consumers. Purchase behaviour is a key point for consumers to access and evaluate the specific product. Ghosh (1990) states that purchase intention is an effective tool to predict buying process. Purchase intention may be changed under the influence of price or perceived quality and value. In addition, consumers are affected 
by internal or external motivations during the buying process (Gogoi, 2013). Researchers have proposed six stages before deciding to buy the product, which are: awareness, knowledge, interest, preference, persuasion (Kotler and Armstrong, 2010) and purchase (Kawa, Rahmadiani and Kumar, 2013).

Fig. 1: A model for systematization the literature on consumer behaviour and purchase intentions

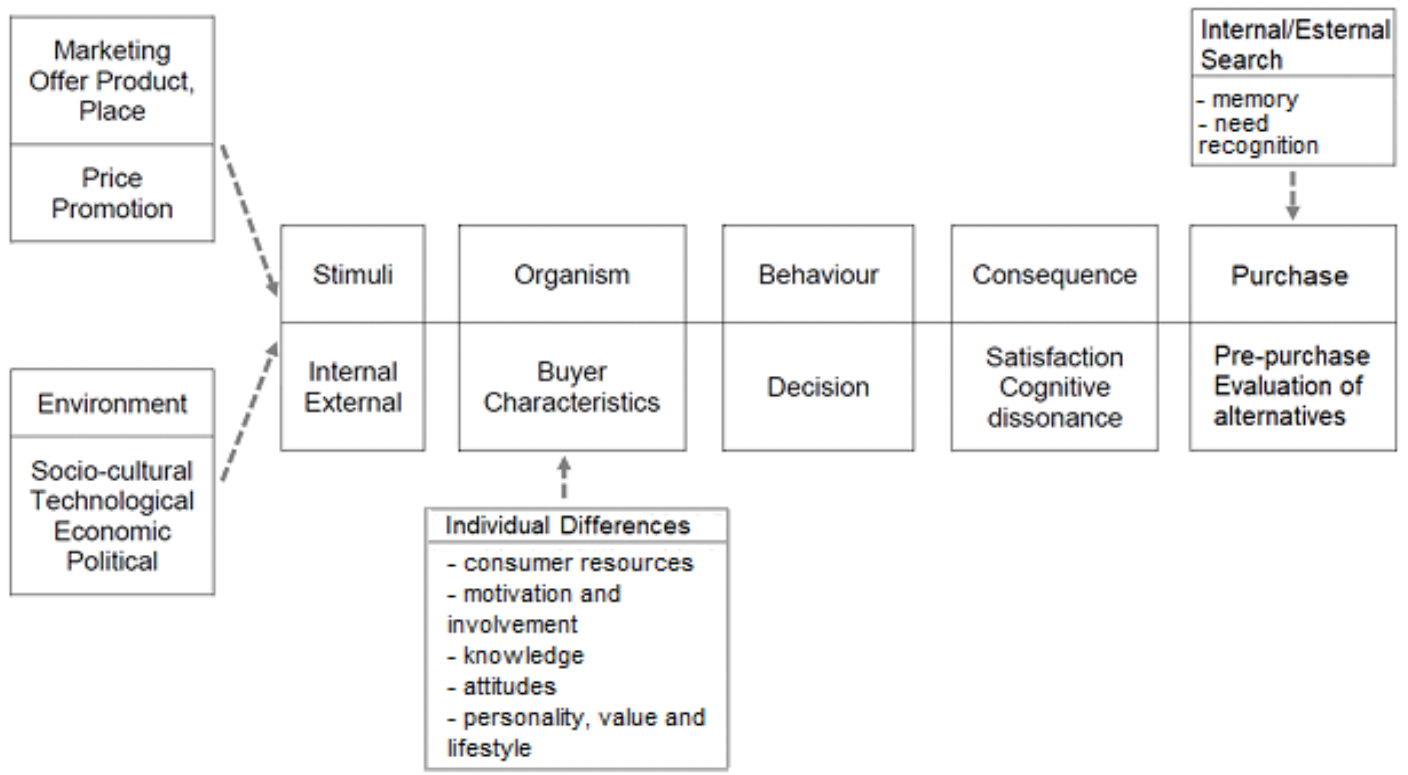

Source: adapted from Mehrabian and Russell, 1974.

\section{Methodology}

In recent years, researchers in marketing psychology have increasingly become interested in short-term processes and everyday experiences of working individuals. Diaries provide the necessary means to examine these processes (Ohly, Sonnentag, Niessen and Zapf, 2010). Although, diary studies have become more popular in recent years, researchers not familiar with this method still find it difficult to get access to the required knowledge. In this paper, a diary study example is used.

The research was carried out through a qualitative method through the support of diary tool, aims to highlight what is at the base and what determines the consumer's choices. The daily diary methodology became an important tool in research on consumer behaviour (Gunthert and Wenze, 2012). In diary studies, people provide frequent reports on the events and experiences of their daily lives. These reports capture the particulars of experience in a way that is not possible using traditional designs (Bolger, Davis and Rafaeli, 2003). Indeed, is a key method used by social and personality psychologists in their research (Nezlek, 2012). The consumer's diary (Bolger et al., 2003) used has a guided structure and consists of four information areas (see appendix) that describe the daily purchasing activity of the interviewed. At the end of each day, during a 30-day observation period, the latter completed the pages of the diary, providing the information requested in the specific information fields. Specifically, the process of daily spending of 10 individuals (responsible for the purchase of their own family group), which live in the province of Naples (in the Campania region) in relation to the categories of food products, detergents and body care was analyzed. For a period of thirty days starting from the month of January 2017 the respondents (table 2) have compiled a diary answering specific questions about which products were purchased in that day, where and why they had bought them and finally what they had learned on that day in make purchases. Specifically, at the first question the respondent had to indicate the store's type that he had visited making daily purchases.

Operatively, it was necessary to indicate if they had made purchases: in small traditional specialized areas (such as butchers or greengrocers), in sales areas without fixed physical structure (such as local markets or street vendors), in large modern distribution facilities and in sales platforms online, 
bio-products or farm-to-table (Tippins, Rassuli and Hollander, 2002). In the second question, the respondent had to indicate the motivations that determined his purchase choices previously indicated. In the third part he indicated which products he had purchased (in the various sales formats) and finally he was asked to indicate any observations, advice and suggestions deriving from his purchase experience. Moreover, with the same respondents of the diaries, in-depth interviews (Legard, Keegan and Ward, 2003; Coombes, Allen, Humphrey and Neale, 2009; Mears, 2012) were conducted to better understand what they had described, as well as to be able to individuate new elements that did not emerge in the previous research methodology. The experience collected in the diary is not a finished product but must be considered as a raw material that must be submitted to a series of complementary treatments and analyzes. The consumer's experience is considered a first version of reality and the researcher must consider the gap, deep but always existing, between the objective reality and the subjective representation of the narrator (Poirier, 1983). After this consideration, we will propose results to better understand the variables that have influenced the purchase choices over time. This represents the central objective of the work, that is the research and identification of the variables and factors involved in the purchasing process of FMCGs in grocery retailing (Fornari E., Fornari, D., Grandi and Menegatti, 2013).

\subsection{The ethnographic research and diaries tool}

The method of ethnographic research reflects the fact that every expression of man is independent of culture and society (Elliott and Jankel-Elliott, 2003). There are four characteristics that distinguish this methodology: the use of diary as a tool (in appendix), the field work, the cyclic nature of data collected, the focus on culture and the immersion in culture. This latter was realized by the researcher in an indirect way, through the use of the diaries made daily by consumers. The people chosen for our research live in the province of Naples, so they have the influence of the local culture, as well as the economic and social aspect of the Campania region. The researcher's job is to try to record, in an orderly manner, how these subjects behave and how they explain their behaviour acquired from their point of view influenced by their culture of belonging. This study was implemented, as was mentioned above, using the monthly diary where everyone had to list the purchase choices and underlying motivations, as well as what he had learned during these daily actions. Grounded theory scholars (Strauss and Corbin, 1994) argue that it is important to prevent preconceived ideas from diverting data collection. There is in fact the danger of grasping from the field only what the interpretative project suggests due to an excessive theoretical articulation of the cognitive question. This can be avoided only if the members of the culture under study can oppose the researcher's prejudices. For example, through the systematic use of verification procedures (such as interviews and focus groups) and the solicitation of comments by these people about the interpretations made by the researcher. The diary represents a qualitative methodology research (Biggerstaff and Thompson, 2008) that focuses on individuals, and specifically, on their experiences. The goal is to report in textual form: the thoughts, ideas, attitudes and perceptions of the respondent (Gunthert and Wenze, 2012). This research approach emphasizes human behaviour and social interaction, exploring the quality of a phenomenon rather than quantitative aspects. As mentioned, the purpose of the qualitative methodology (Silverman, 2013) is to develop new knowledge based on the beliefs and experiences of the participants and not on predefined hypotheses to be verified. It is inductive rather than deductive and is interpretative rather than predictive. The structure is generally flexible and therefore requires the researcher the ability to change and adapt the research process in accordance with emerging results.

The qualitative methodology is therefore different from quantitative research as it is characterized by a certain flexibility throughout the research process (Denzin and Lincoln, 1994). Through the diary, the person in charge, describes in the form of free narration, all the information deemed relevant for the research or for the understanding of the event to be described. It is essential that the diary is not drawn up with the intention of objectively reporting what is happening, but that on the contrary it brings the event and the point of view of the narrator/observer as faithfully as possible. The fundamental problem of observation is objectivity. This objectivity is approached through the internal world of the observer, which is not intended as an indifferent recorder of events, but a set of thoughts and feelings that enter the cognitive process and whose reading code can be broad, open to possibility and to the different or vice versa, closed and prejudicial (Bion, 1962). The narration (Elliott, 2005) in the diary refers to a specific 
temporal sequence that coincides with the observation period. In the specific case, this is a 30-day text that should contain all the elements to reconstruct the temporal sequences useful for making an ex post reflection on the purchasing experience. To understand an emotionally complex and not easily interpretable phenomenon as the choices of consumers, there is the need to adopt methods that are less rigid and objective. By entrusting to a person, the compilation of a diary of their emotions to record all the episodes experienced, it is possible, unlike a questionnaire, to limit the negative effects of retrospective memory and to have information in progress, even if obviously not they can completely cancel the distortion effects deriving from self-observation (Gephart, 2004). The diary can be structured in different ways, with more open/closed questions or a mix between the two choices, as done in this work. Or, it could focus more on the quantification of the emotional experience than on investigating personal reworking from the qualitative point of view. Reporting through the diary is a research methodology that collects qualitative information about specific activities or specific experiences of the study in question.

This data collection uses a longitudinal technique, i.e. it studies the same variables over a period so this research tool, although not able to provide detailed results as it happens in a real field study, can offer a great deal of information context without having to bear the costs of the latter. Therefore, the advantages of the studies mediated by the diary are numerous. In fact, they allow the collection of longitudinal and temporal information, reporting of contextualized events and experiences, determining the antecedents, the correlations and the consequences of everyday experiences. In compiling the diary in question, the person in charge had to answer 5 questions, namely: 1. "Where did you buy, in which store?"; 2. "Why did you buy in that store?"; 3. "What categories of products did you buy?"; 4. "Why did you buy those products in the shops indicated above?" and 5. "What did you learn today in making purchases?". Basically, the first and third questions are quantitative (on visiting frequencies) since they are useful to indicate a habit as they specify the categories, the types of purchases and the chosen distribution formats. The other questions are more qualitative and are useful for understanding the reasons behind the purchase decisions. Through the analysis of the answers reported in the 30 days we aim to better understand the purchasing behaviour of the consumer (of food and chemicals products) and what determines his choices, perhaps to confirm or disprove the theories currently shared.

A continuum marked by regularity and constancy, through repeated questions and answers. The diary filled in during the participant observation, later becomes a datum to analyze. To complete the work with the samples, it was decided to use a final interview with all 10 respondents to better understand some aspects not highlighted in the diaries. It becomes fundamental in data collection, verify truthful and relevant information, the openness and confidentiality of the subjects, the spontaneity and the sincerity of the discourses and responses of the individuals.

Tab. 2: Characteristics of survey sample

\begin{tabular}{|l|l|l|l|l|}
\hline \multicolumn{2}{|l}{ Profile } & \multicolumn{2}{l}{ Age } & \multicolumn{2}{c|}{ Working } \\
status & \\
\hline & $F$ & 45 & Psychologist & 5 (persons) \\
2 & $F$ & 50 & Secretary & 4 \\
3 & $F$ & 40 & Housewife & 4 \\
4 & $F$ & 50 & Housewife & 4 \\
5 & $M$ & 42 & Professor & 1 \\
6 & $F$ & 44 & Housewife & 5 \\
7 & $F$ & 31 & Housewife & 3 \\
8 & $F$ & 40 & Housewife & 4 \\
9 & $F$ & 32 & Housewife & 4 \\
10 & $F$ & 59 & Teacher & 5 \\
\hline
\end{tabular}

Source: own elaborations. 


\subsection{Content analysis: axial coding and in-depth interviews}

The content analysis associated with a rather broad and heterogeneous set of methods and tools, can be considered as a family of techniques (belonging to the social science domain) oriented to the study of empirical manuscripts that we can define "informant documents". The content analysis, done on the diaries (and on subsequent in-depth interviews) has in its scope the production of valid and reliable inferences (Stemler, 2001), following an abductive approach (Timmermans and Tavory, 2012). Content analysis is therefore a research methodology that identifies in an objective way certain characteristic present in a text that in our case are represented by the analysis of the diary, for the quantitative questions present in them.

\section{Findings}

Figure 2 highlights the frequency of monthly visits by respondents in the various distribution formats (both for the purchase of food and chemical products). In order we have: 1. small specialized and traditional areas, such as butchers, bakeries, delicatessens, greengrocers; 2. sales areas without a fixed physical structure, such as local markets, street vendors and fairs, 3. large structures and stores chain of modern distribution (e.g. supermarkets and hypermarkets) and 4. online purchases, bio and farm to table products.

Fig. 2: The distribution format preferred by the sample

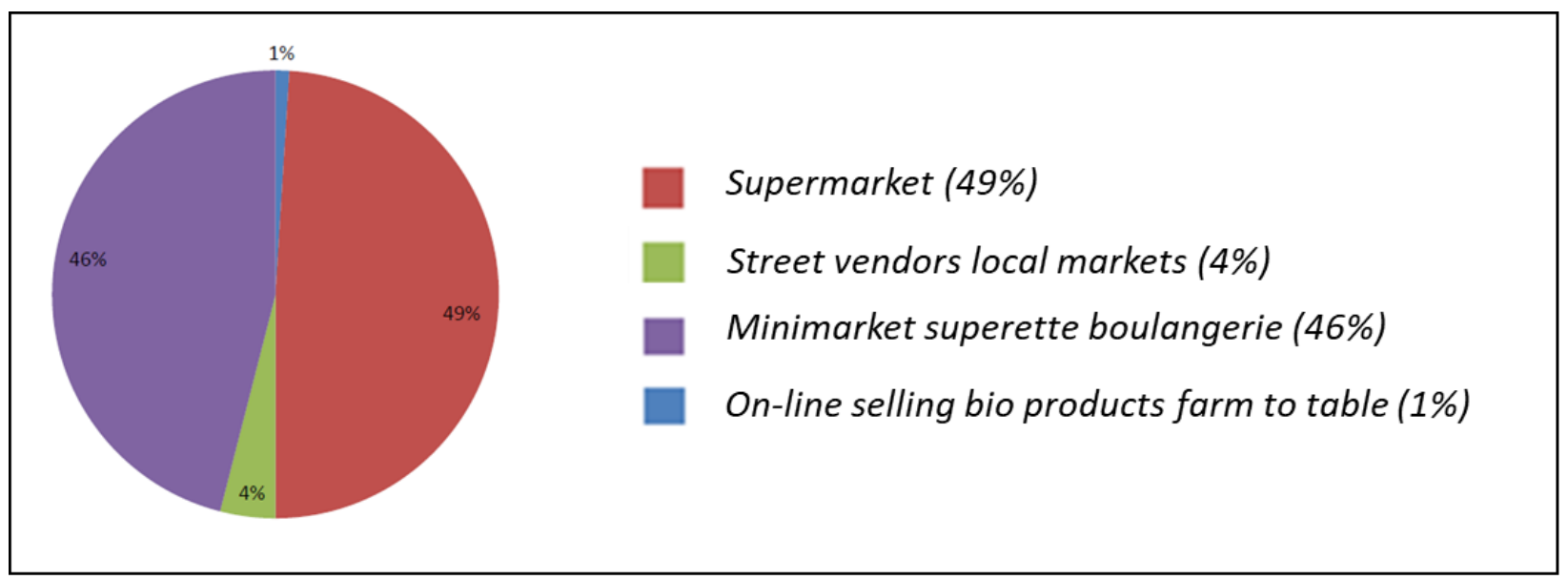

Source: own elaborations.

Each interviewee visited the small traditional specialized areas 138 times a month, the surfaces without physical structure only 12 times and the large surfaces of modern distribution even 147 times $^{1}$. Traditional shops, although they are more easily accessible and cover a greater part of the territory in question than modern distributors, are visited less frequently. It must be said, however, that for the purchase of fresh counter products such as meat, fish, fruit and vegetables are made for all ten respondents more in the traditional format of proximity. This is important because it represents a strategic lever for the innovation of the internal layout of retailers who want to attract also this type of clientele (or to re-create the corners of traditional shops inside the supermarket in terms of customer's experience and trust with the consumer). On average, the supermarket is visited for the food purchase and chemical products (for example, household cleaning and personal care products) almost once a day. This confirms that consumers' buying habits are changing, and the traditional trust store under the house is completely giving way to supermarkets and hypermarkets, especially about the cost of canned food and other shelf products such as pasta, sauces. ready, legumes, biscuits and drinks (figure 3). In all 10 cases, the cost of these products is in fact greater in these formats and in two cases even in an exclusive manner. Non-food

${ }^{1}$ The share of visit is calculated on the total of 300 potential gross visits of the 10 respondents, in the period $t$ in question (that is, 30 days). 
items, and therefore chemical products for personal care and home care, are purchased for 3 people out of 7 exclusively in traditional shop while the other three people rely exclusively on large-scale retail chain. This data implies that the choice of format for these products is linked to purchasing habits and that is why it never changes supplier. The last type of distribution format, such as online and bio products, was used in the month considered only 3 times by a single person of the 10 in question. Even less the organic and finally the format farm to table have never even been chosen. It is therefore clear that the revolutionary wave of online sales and people's awareness of the environmental impact of products has not yet fully influenced the analyzed samples, which are still linked to traditional formats and large retail chains. In these specific cases, according to the interviewed samples, one can does not enjoy the convenience and peculiarity deriving from online shopping because of the lack of practicality with the IT tool and for the delivery times that are not yet immediate.

Fig. 3: purchases by product category

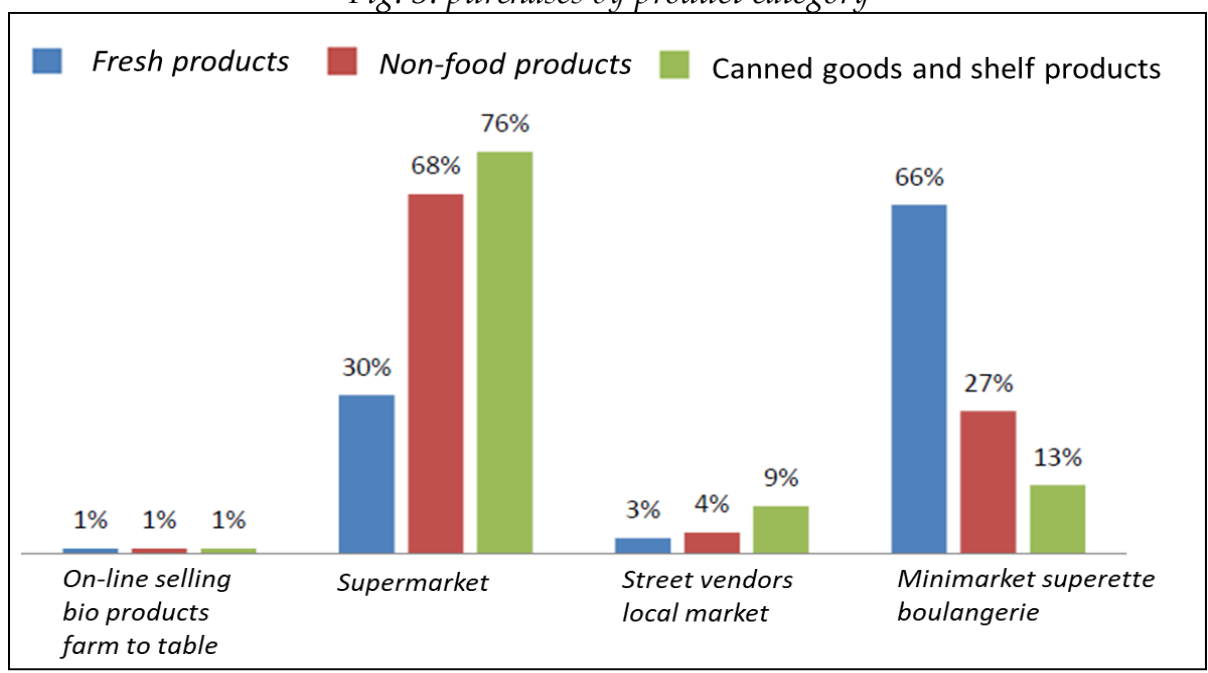

Source: own elaborations.

After examining the quantitative data, an axial coding (Kendall, 1999) was made on the answers concerning the qualitative questions. Specifically, the compilation of diaries foresaw questions in relation to the reasons underlying the choices of distribution formats and products purchased. One of the most commonly used qualitative research tools is typically the interview, which can be structured in different ways. The type that has been used in this research is specifically that semi-structured (in which there is a scheme that defines the main themes) but their order of treatment is not pre-established. The codification ends with the analysis of the answers (Costantino, Raffaghelli, Alvarez and Moran, 2012), starting from the recordings made on the respondents and expanding the main concepts emerged during the interview. The individual interview in depth analyzed below, is a qualitative research technique that involves a "semi-free" conversation between a researcher and a selected subject, during which the interviewee can freely express in detail their opinions and attitudes on a specific topic as can be its way of acting in making purchases. This technique is aimed at examining a topic from the interviewee's point of view. In the guided conversation through a discussion track composed of 5 questions, so that no aspect of the topic in question is left out, while leaving the interviewee free to express himself, the participant gets to look at himself from the outside, critically, thus being able to understand more clearly and to explain the emotions, attitudes and motivations that drive his purchase choices.

The axial coding that will be elaborated below is a process that correlates the consumer's responses to a qualitative question and through a combination of inductive and deductive thinking these answers will be linked, after a codification, to certain variables, in turn related to some macro factors. It will then rise to the level of logical aggregation to get to highlight the most interesting fields from a practical point of view that influence consumer decisions. Axial coding consists in the reorganization of data to reach connections between the different categories, and between categories and any sub-categories processed (Pandit, 1996). This coding is carried out through a series of procedures and comparisons. We start from causal conditions, i.e. events and events that drive the development of a phenomenon. By phenomenon 
we mean the event to which a set of actions are related. Everything is influenced by the context that represents the set of conditions in which the actions take place. We continue with the axial coding of the answers to qualitative questions to understand respectively why they bought in that format and why they chose the precise products produced in that format (the summary information, resulting from the coding of the lexical correspondences in the questionnaires and in interviews transcription, are highlighted in figure 4). Starting from the question concerning the reasons underlying the choice of a distribution format, 10 variables were summarized in which the motivations highlighted by the consumer can be cataloged. These variables impact on share of wallet (SOW) of a retailer and can be classified into four factors which express the conditions that push the consumer to make certain purchasing decisions. Specifically, the tables highlight the following macro factors: staff skills, product/format characteristics and personal factors.

\section{Discussion}

Examining the collected data, the reliability of the sales staff, attributable to the empathy of these subjects, can significantly influence the customer's perception and the quality of the service provided. Establishing a relationship of trust becomes essential to create lasting relationships and to direct people to choose the same format and make the customer less flexible to changes in price (especially with substantial price increases). The employee availability and the trust that customers place in these subjects are the variables that fall within the "staff skills" factor which guides the choice of the consumer in $24 \%$ of cases (percentage of frequency of the lexical correspondences codified on this factor). In most cases this factor influences the choice of traditional formats such as butchers, fishmongers and delicatessens in which the internal and most familiar environment can create that atmosphere for an informal relationship between the customer and the sales staff. The products quality, promotions and price levels account for $16 \%$ in the choice of format. In the consumer's mind, the traditional shop possesses higher quality goods especially for more expensive categories such as meat and fish. Promotions, on the other hand, have a greater impact on large-scale retail channels where flyers and advertising play an important role also in relation to the larger sales area. The format characteristics impact for $29 \%$ of people consider important variables such as the assortment on the shelves, the location of the store (close to points of interest or transit areas and traffic) and the quality of service offered (for example the cleaning of the spaces or the opening in extraordinary hours). Finally, there are factors that are strongly linked to the culture of own city or to personal characteristics of each respondent. These represent complementary services and, in some cases, customized, such as the ease of parking, the possibility of home delivery or ordering the shopping by telephone (behavioural factors). Or other emerged insights such as the inquisitiveness to experiment new stores and especially the proximity of the latter to their home (or workplace) that is essential to time saving.

\section{Fig. 4: factors influencing purchase decisions}

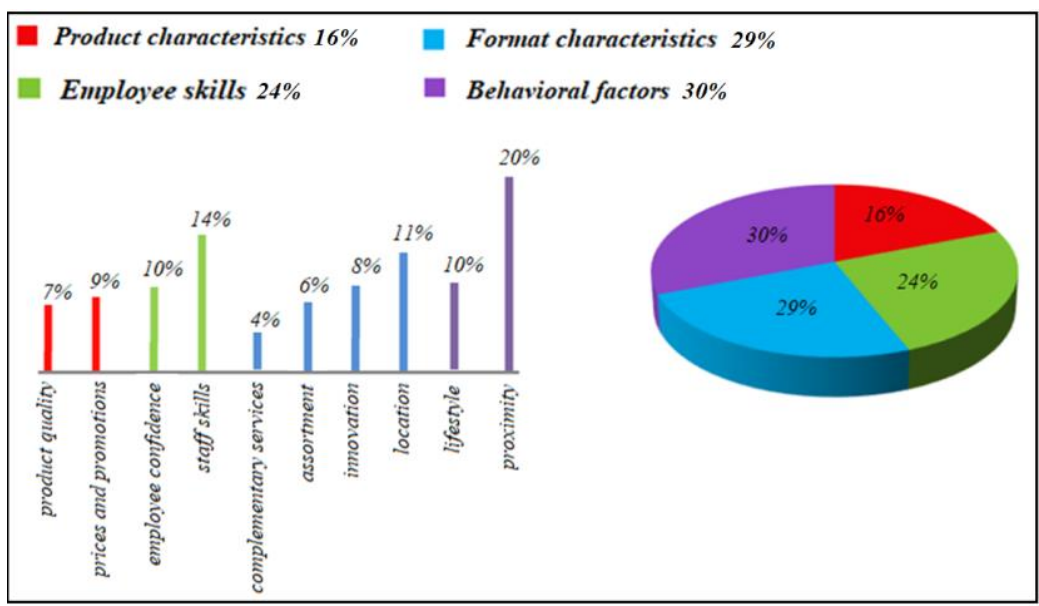

Source: own elaborations. 


\section{Conclusion and managerial implications}

First, it can be noted that the symbolic/emotional component, which is on the rise in the studies of contemporary marketing, is not very common in respondents. Emotions, feelings, smells and atmospheres are not in fact crucial in the reasons for the choice of a point of sale by these consumers. These elements certainly influence the consumer's choices, but the latter does not consider it essential or at least cannot clearly perceive it to the point of highlighting it. On the contrary, one of the factors that are perhaps the most underrated at managerial level, but extremely important for the client, is the relationship created with sales personnel. The relationship established with the traders of the traditional structures visited habitually pushes the person to also trust the quality of the products he buys. Especially in butcheries or fishmongers, this fiduciary relationship and the intimate and almost familiar atmosphere of the store become essential factors of influence. As has emerged from both the diary and the telephone interviews in fact meat and fish, and in general all the fresh counter products that require a high level of quality to be chosen, are purchased in most cases in small traditional shops. This relationship of trust, paradoxically, is not created in the formats of modern organized distribution where instead checks on the provenance of goods are in theory closer. All this, according to what emerged from the interviews, happens because the products that are typically found in the pre-wrapped or already packed supermarket to speed up the delivery process, reduce files and confusion in the departments do not inspire confidence and do not transmit security to the consumer who instead prefers the calm and tranquility of a small traditional shop, where you can exchange a word more with the seller on the quality of the product and be reassured. In the structures of large distribution, instead, the selected samples are more likely to buy canned goods and shelf products in general, following a common logic, promotions. In fact, if for fresh products confidence in the quality of products becomes a primary factor, for this other type of products the process of spending becomes a hunt for savings. People also prefer to get away from home, perhaps to spend an afternoon in shopping centers or just to take advantage of certain discounts or loyalty cards (HILO, business model $^{2}$ ), just for the desire to accumulate these products in large quantities saving on the total, perhaps even at the expense of quality.

A similar situation has emerged for the chemical products suitable for personal and household care, for which the expenditure process involves the acquisition of large quantities in a single solution to create stocks to be used the rest of the week. The expense of the latter is based on the habit and knowledge of the brand that you usually choose. In this merchandise sector, in fact, respondents rarely experimented with innovative products or different brands. Another choice factor of the point of sale, and probably the most important and determinant of all, is proximity. The proximity of a distribution format to areas often frequented by respondents (places close to public buildings such as schools, from their workplace or home) affects the choice of the store in which to purchase. So, the retailer should aim to facilitate the delivery of the service by saving time when making purchases or using a more transparent pricing strategy, where low prices are offered every day the consumer does not have to continuously compare promotional flyers or change store (EDLP, business model $^{3}$ ).

Another relevant data emerging from the analysis is that related to staff skills. The competence, friendliness and availability invite the latter to choose a specific point of sale. These evidences can lead to consequences regarding the selection and recruitment methods of personnel based on character requirements and skills that go towards establishing empathy with the client. Finally, the sale on online channels for both the purchase of food products and chemicals is not very frequent. Since this is an ethnographic analysis, this is certainly closely related to the culture of the chosen locality such as the Campania region. In fact, the samples are still tied to traditional spending habits, but considering that most of the times the choices of the stores fall on proximity due to the limited time available, it may seem a paradox not to exploit the features of the network. The respondents, however, pointed out the lack of practicality with the Internet tool and this may have influenced the results of the analysis carried out at least about this of purchase methodology. In summary, there are the following considerations:

- The head of household purchases is often a woman;

2 Fassnacht, 2013.

${ }^{3}$ Hoch, et al., 1994. 
- canned food products are mostly bought in the supermarkets while fresh products (such as meat, fish, bread and fruit) are purchased in small traditional specialized stores;

- female buyers pay more attention to attributes such as layout (e.g., cleaning spaces) and store atmosphere compared to male consumers;

- the store location, the payment at cash desk, the assortment, the sales staff empathy and the value for money represent yet strategic levers for retailer for creating customer's value.

\section{Limitations and suggestions for future research}

The first preliminary consideration to make, is that, although it is a quantitative research methodology (e.g. structured questionnaire), the data have been treated in a qualitative way, so the different references to percentages and statistical inferences are of an accidental nature to the end of the understanding of the phenomenon. The main research limitations are related to an ethnographic approach and qualitative methods (Opdenakker, 2006) during the first explorative step. The problem of ethnographic researcher with reliability is caused by the fact that ethnographic research occurs in natural setting and focuses on processes (Wiersma 1986 and Burns, 1994). The diaries are considered an ethnographic research tool, and offer us, an immersion in the local culture. But this immersion in culture is required for the researcher and not of the research subjects, in our case the respondents of the journals. It must be said, however, that the diary tool was created by the researcher both in its structure and in the content that is supported in the data collection phase.

The accurate replication is very difficult to achieve because an event in natural setting cannot be reproduced. However, this problem might be addressed by describing the methodology as comprehensive as possible so that the next researcher can reconstruct the original analysis strategies. Another problem is that replication of the findings is based on researchers' agreement so that the findings can be replicated. Wiersma (1986) and Burns (1994) claim that it's difficult to replicate the findings because ethnographic research requires an accurate description of the phenomena under study. However, the flow of information to support the accurate description might vary (Nurani, 2008). That is why one researcher will probably have thicker description than another researcher. This situation will lead to different interpretation. In dealing with this problem, the researchers must find the cause of disagreement from the description itself so that there is a chance to discuss and to resolve the disagreement. This limitation can be overcome by using procedure to enhance the external validity such as multi-site studies and variations of the research context. More replications in other industry are needed to enhance the generalizability of our findings, from retailing to other industry or in other country. Despite the limitations of the ethnographic approach, it has benefits for research in naturalistic setting such as classroom research, language learning process in a speech community, and so forth. The primary advantage of ethnography is its observational technique that allows researcher to record the behaviour as it occurs. Furthermore, it will uncover and thoroughly describe the phenomena in a community. The last advantage of ethnography research is to understand the phenomenon under study from the perspective of those being studied. Therefore, the finding is more real than a research that manipulates variables by using external experiments.

\section{References}

Acebrón, L. B., \& Dopico, D. C. (2000). The importance of intrinsic and extrinsic cues to expected and experienced quality: an empirical application for beef. Food quality and preference, 11(3), 229-238.

Ahmetoglu, G., Furnham, A., \& Fagan, P. (2014). Pricing practices: A critical review of their effects on consumer perceptions and behaviour. Journal of Retailing and Consumer Services, 21(5), 696-707.

Ajzen, I. (1991). The theory of planned behaviour. Organizational behaviour and human decision processes, 50(2), 179-211.

Al-Debei, M. M., \& Avison, D. (2010). Developing a unified framework of the business model concept. European Journal of Information Systems, 19(3), 359-376.

Arnould E. J., \& Thompson, C. J., Consumer culture theory (CCT): Twenty years of research. Journal of consumer research, 31(4), 2005, pp. 868-882.

Aschemann-Witzel, J., Jensen, J. H., Jensen, M. H., \& Kulikovskaja, V. (2017). Consumer behaviour towards pricereduced suboptimal foods in the supermarket and the relation to food waste in households. Appetite, 116, 246258 . 
Backhaus, K., Becker, J., Beverungen, D., Frohs, M., Müller, O., Weddeling, M., ... \& Steiner, M. (2010). Enabling individualized recommendations and dynamic pricing of value-added services through willingness-to-pay data. Electronic Markets, 20(2), 131-146.

Banerjee, A., \& Drollinger, T. (2017). Store within a store: Matched versus mismatched image perceptions. Journal of Retailing and Consumer Services, (36), 53-61.

Bayton, J. A. (1958). Motivation, cognition, learning: Basic factors in consumer behaviour. The Journal of Marketing, 282289.

Bearden, W. O., \& Netemeyer, R. G. (1999). Handbook of marketing scales: Multi-item measures for marketing and consumer behaviour research. Sage.

Berman, B., Evans, J. R., \& Chatterjee, P. (1995). Retail management: A strategic approach.

Biggerstaff, D., \& Thompson, A. R. (2008). Interpretative phenomenological analysis (IPA): A qualitative methodology of choice in healthcare research. Qualitative research in psychology, 5(3), 214-224.

Bion, W. R. (1962). Apprendere dall'esperienza (trad. it.: Roma: Armando, 1972).

Bray J. P., Consumer behaviour theory: approaches and models, 2008, p. 3.

Belk R. W., Situational variables and consumer behaviour. Journal of Consumer research, 1975, pp. 157-164.

Blackwell, R., DSouza, C., Taghian, M., Miniard, P., \& Engel, J. (2006). Consumer behaviour: an Asia Pacific approach. Thomson.

Bolger, N., Davis, A., \& Rafaeli, E. (2003). Diary methods: Capturing life as it is lived. Annual review of psychology, 54(1), 579-616.

Burns, R.B. 1994. Introduction to Research Methods. Melbourne: Longman Cheshire.

Campbell C., The Craft Consumer Culture, craft and consumption in a postmodern society. Journal of consumer culture, Cacucci Editore, Bari, 2005, pp. 23-42.

Cantone, L., \& Testa, P. (2011). Customer knowledge competence, consumer insight interpretive techniques and competitive advantage of the firm. Journal of Marketing Trends, 1(4), 7-14.

Cantone, L. Basile V., \& Testa, P. (2018). "Comparing business models in the grocery retailing industry: a conceptual framework proposal". Referred Electronic Proceedings, Sinergie-SIMA Conference, Ca' Foscari University of Venice, Italy, 14-15 June 2018 - ISBN 97888943937-2-9.

Castaldo, S., Grosso, M., \& Premazzi, K. (2018). Experience retail: le nuove funzioni del punto di vendita nell'omni-channel economy.

Castaldo, S., \& Mauri, C. (Eds.). (2017). Store management: Il punto vendita come luogo di customer experience. FrancoAngeli.

Cercola, R. (1990). La gestione delle qualità nell'impresa di servizi.

Chaffey, D., \& Ellis-Chadwick, F. (2019). Digital marketing. Pearson UK.

Chang, T. Z., \& Wildt, A. R. (1994). Price, product information, and purchase intention: An empirical study. Journal of the Academy of Marketing science, 22(1), 16-27.

Chang, H. J., Eckman, M., \& Yan, R. N. (2011). Application of the Stimulus-Organism-Response model to the retail environment: the role of hedonic motivation in impulse buying behaviour. The International Review of Retail, Distribution and Consumer Research, 21(3), 233-249.

Chakrabortty, R. K., Hossain, M. M., Farhad, M., Azad, H., \& Islam, M. J. (2013). Analysing the effects of sales promotion and advertising on consumer's purchase behaviour. World, 3(4).

Cillo, P., \& Verona, G. (2001). Il Management nell'Era della Connessione. Dalla Catena Fisica alla Rete Virtuale del Valore.

Collins-Dodd, C., \& Lindley, T. (2003). Store brands and retail differentiation: the influence of store image and store brand attitude on store own brand perceptions. Journal of Retailing and Consumer Services, 10(6), 345-352.

Coombes, L. I. N. D. S. E. Y., Allen, D., Humphrey, D., \& Neale, J. O. A. N. N. E. (2009). In-depth

interviews. Research methods for health and social care, 197-210.

Copeland, B. R., \& Kotwal, A. (1996). Product quality and the theory of comparative advantage. European Economic Review, 40(9), 1745-1760.

Costantino, G., Raffaghelli, J., Alvarez, G., \& Moran, L. (2012). Qualitative research methods to analyze Learning 2.0 processes: Categorization, recurrence, saturation and multimedia triangulation. Journal of e-Learning and Knowledge Society, 8(2), 123-133.

Cristini, G., \& Laurini, F. (2017). Growth factors of store brands in different store formats in Italy.

The International Review of Retail, Distribution and Consumer Research, 27(2), 109-125.

Cristini, G., \& Zerbini, C. (2017). SBs Purchase Determinants in Italian Market: A Survey of Different Retailers' Shoppers. International Business Research, 10(8), 1.

Cummings, W. H., \& Venkatesan, M. (1976). Cognitive dissonance and consumer behaviour: A review of the evidence. Journal of Marketing Research, 303-308.

Day, D., Gan, B., Gendall, P., \& Esslemont, D. (1991). Predicting purchase behaviour. Marketing Bulletin, 2(5), 18-30. 
Denzin, N. K., \& Lincoln, Y. S. (1994). Handbook of qualitative research. Sage publications, inc.

De Mooij, M., \& Hofstede, G. (2011). Cross-cultural consumer behaviour: A review of research findings. Journal of International Consumer Marketing, 23(3-4), 181-192.

Donovan R. J., Rossiter J. R., Marcoolyn G., \& Nesdale, A., Store atmosphere and purchasing behaviour, Journal of retailing, 70(3), 1994, pp. 283-294.

East, R., Singh, J., Wright, M., \& Vanhuele, M. (2016). Consumer behaviour: applications in marketing. Sage.

Elliott, R., \& Jankel-Elliott, N. (2003). Using ethnography in strategic consumer research. Qualitative market research: An international journal, 6(4), 215-223.

Elliott, J. (2005). Using narrative in social research: Qualitative and quantitative approaches. Sage.

Fassnacht, M., \& El Husseini, S. (2013). EDLP versus Hi-Lo pricing strategies in retailing-a state of the art article. Journal of Business Economics, 83(3), 259-289.

Ferraresi M., La società del consumo. Lessico della postmodernità, p. 15.

Ferreira, A. I., \& Ribeiro, I. (2017). Are you willing to pay the price? The impact of corporate social (ir) responsibility on consumer behaviour towards national and foreign brands. Journal of Consumer Behaviour, 16(1), 63-71. ISO 690.

Foxall, G. R., Oliveira-Castro, J. M., James, V. K., \& Schrezenmaier, T. C. (2011). Consumer behaviour analysis and the behavioural perspective model. Management Online Review.

Gardner, M. P. (1985). Mood states and consumer behaviour: A critical review. Journal of Consumer research, 12(3), 281300.

Haugtvedt, C. P., Petty, R. E., \& Cacioppo, J. T. (1992). Need for cognition and advertising: Understanding the role of personality variables in consumer behaviour. Journal of Consumer Psychology, 1(3), 239-260.

Havlena, W. J., \& Holbrook, M. B. (1986). The varieties of consumption experience: comparing two typologies of emotion in consumer behaviour. Journal of consumer research, 13(3), 394-404.

Foxall G., Consumer psychology in behavioural perspective, Beard Books, 1990, pp. 174-177.

Fornari, E., Fornari, D., Grandi, S., \& Menegatti, M. (2013). The influence of retailing-mix levers on private label market share: The case of the Italian FMCG market. Journal of Retailing and Consumer Services, 20(6), 617-624.

Frieda Fromm-Reichman, An Outline of Psychoanalysis (New York: Random House), 1955, p. 113.

Gajjar, D. N. (2013). Factors affecting consumer behaviour. International Journal of Research in Humanities and Social Sciences, 1(2), 10-15.

Gephart, R. P. (2004). Qualitative research and the Academy of Management Journal. Academy of management journal, 47(4), 454-462.

Geertz, C. (1973). The interpretation of cultures (Vol. 5019) Basic books.

Gilbride, T. J., Currim, I. S., Mintz, O., \& Siddarth, S. (2016). A Model for Inferring Market Preferences from Online Retail Product Information Matrices. Journal of Retailing, 92(4), 470-485.

Giampaolo, F. (2003). Il nuovo consumatore: verso il postmoderno. Milano, Franco Angeli srl, 2003-ISBN, 615974799.

Grosso, M., \& Castaldo, S. (2015). How store attributes impact shoppers' loyalty: do different national cultures follow the same loyalty building process? The International Review of Retail, Distribution and Consumer Research, 25(5), 503515.

Gunthert, K. C., \& Wenze, S. J. (2012). Daily diary methods.

Gunter, B., \& Furnham, A. (2014). Consumer Profiles (RLE Consumer Behaviour): An Introduction to Psychographics (Vol. 5). Routledge.

Gummesson, E. (2005). Qualitative research in marketing: Roadmap for a wilderness of complexity and unpredictability. European journal of marketing, 39(3/4), 309-327.

Herche, J. (1994). Ethnocentric tendencies, marketing strategy and import purchase behaviour. International Marketing Review, 11(3), 4-16.

Hoch, S. J., Dreze, X., \& Purk, M. E. (1994). EDLP, Hi-Lo, and margin arithmetic. The Journal of

Marketing, 16-27.

Hoyer, W. D., \& Stokburger-Sauer, N. E. (2012). The role of aesthetic taste in consumer behavior. Journal of the Academy of Marketing Science, 40(1), 167-180.

Jacoby, J. (2002). Stimulus-Organism-Response Reconsidered: An Evolutionary Step in Modeling (Consumer) Behaviour. Journal of Consumer Psychology, 12(1), 51-57.

Jeddi S., Atefi Z., Jalali M., Poureisa A., \& Haghi H., Consumer behaviour and consumer buying

decision process, International Jounal of Business and Behavioural Sciences, 2013, pp. 1-4.

Kawa, L. W., Rahmadiani, S. F., \& Kumar, S. (2013). Factors affecting consumer decision-making: a survey of young adults on imported cosmetics in Jabodetabek, Indonesia. SIJ Transactions on Industrial, Financial \& Business Management, 1(5), 175-180.

Kendall, J. (1999). Axial coding and the grounded theory controversy. Western journal of nursing research, 21(6), 743757. 
Kim, J., \& Lee, H. H. (2008). Consumer product search and purchase behaviour using various retail

channels: the role of perceived retail usefulness. International Journal of Consumer Studies, 32(6), 619-627.

Kim, J. O., Forsythe, S., Gu, Q., \& Jae Moon, S. (2002). Cross-cultural consumer values need and

purchase behaviour. Journal of Consumer marketing, 19(6), 481-502.

Latham, A. (2003). Research, performance, and doing human geography: some reflections on the diary-photograph, diary-interview method. Environment and planning A, 35(11), 1993-2017.

Lewrick, M., Williams, R., Maktoba, O., Tjandra, N., \& Lee, Z. C. (2015). Radical and incremental innovation effectiveness in relation to market orientation in the retail industry: triggers, drivers, and supporters. Successful Technological Integration for Competitive Advantage in Retail Settings, IGI Global, 239-268.

Legard, R., Keegan, J., \& Ward, K. (2003). In-depth interviews. Qualitative research practice: A guide for social science students and researchers, 138-169.

Levy, S. J. (1981). Interpreting consumer mythology: a structural approach to consumer behaviour. The Journal of Marketing, 49-61.

Iida, M., Shrout, P. E., Laurenceau, J. P., \& Bolger, N. (2012). Using diary methods in psychological research.

Lugli, G., \& Pellegrini, L. (2002). Marketing distributive. Utet.

Lugli, G. (1998). I formati di punto vendita nel marketing commerciale e industriale. Trade marketing.

MacInnis D. J., \& Folkes V. S., The disciplinary status of consumer behaviour: A sociology of science perspective on key controversies, Journal of Consumer Research, 2010, pp. 899-914.

Mägi, A. W. (2003). Share of wallet in retailing: the effects of customer satisfaction, loyalty cards and shopper characteristics. Journal of Retailing, 79(2), 97-106.

Maizza A., Sinergie tra Industria e Distribuzione nel settore dei beni di largo consumo,1996.

Mandelli, A., \& Vescovi, T. (2003). Le nuove frontiere del marketing digitale. Etas.

McDonald, M. H., De Chernatony, L., \& Harris, F. (2001). Corporate marketing and service brands-Moving beyond the fast-moving consumer goods model. European Journal of Marketing, 35(3/4), 335-352.

McKechnie G. E., The psychological structure of leisure: Past behaviour. Journal of Leisure Research, 6(1), 1974, p. 27.

McGoldrick, P. J. (2002). Retail marketing. McGraw-Hill.

Mehrabian, A., \& Russell, J. A. (1974). An approach to environmental psychology. the MIT Press.

Meyer-Waarden, L., \& Benavent, C. (2006). The impact of loyalty programmes on repeat purchase behaviour. Journal of Marketing Management, 22(1-2), 61-88.

Mears, C. L. (2012). In-depth interviews. Research methods and methodologies in education, 170-176.

Mehrabian A., \& Russell, J. A., The basic emotional impact of environments. Perceptual and motor skills, 38(1), 1974, pp. 283-301.

Mintz, O., Gilbride, T. J., Currim, I. S., \& Lenk, P. (2016). Metric Effectiveness and Use in Marketing-Mix Decisions: Correcting for Endogenous Selection Effects and Ex-Ante Expectations. Working paper.

Mirabi, V., Akbariyeh, H., \& Tahmasebifard, H. (2015). A study of factors affecting on customers purchases intention. Journal of Multidisciplinary Engineering Science and Technology (JMEST), 2(1).

Morrison, D. G. (1979). Purchase intentions and purchase behaviour. The Journal of Marketing, 65-74.

Rook, D. W. (1985). The ritual dimension of consumer behaviour. Journal of Consumer Research, 12(3), $251-264$.

Schilling, M., \& Izzo, F. (2012). Gestione dell'innovazione. The McGraw-Hill Companies.

Schiffman, L., O'Cass, A., Paladino, A., \& Carlson, J. (2013). Consumer behaviour. Pearson Higher Education AU.

Sorice M., Il consumo performativo. Media e identità dei consumatori mediali, in (a cura di) E. Di Nallo, R. Paltrinieri. Cum sumo. Prospettive di analisi nella società globale. cit., p. 211.

Strauss, A., \& Corbin, J. (1994). Grounded theory methodology. Handbook of qualitative research, 17, $273-285$.

Nezlek, J. B. (2012). Diary methods. Sage.

Nurani, L. M. (2008). Critical review of ethnographic approach. Jurnal sosioteknologi, 7(14), 441-447.

O'brien, T. (1971). Stages of consumer decision making. Journal of Marketing Research, 283-289.

Oestreicher-Singer, G., \& Zalmanson, L. (2013). Content or community? A digital business strategy for content providers in the social age. MIS quarterly, 591-616.

Ohly, S., Sonnentag, S., Niessen, C., \& Zapf, D. (2010). Diary studies in organizational research. Journal of Personnel Psychology.

Opdenakker, R. (2006). Advantages and disadvantages of four interview techniques in qualitative research. In Forum Qualitative Sozialforschung/Forum: Qualitative Social Research (Vol. 7, No. 4).

Pandit, N. R. (1996). The creation of theory: A recent application of the grounded theory method. The qualitative report, 2(4), 1-15.

Pantano, E. (2014). Innovation drivers in retail industry. International Journal of Information Management, 34(3), 344-350.

Park, C. W., Iyer, E. S., \& Smith, D. C. (1989). The effects of situational factors on in-store grocery shopping behaviour: The role of store environment and time available for shopping. Journal of consumer research, 15(4), 422-433. 
Pastore, A., \& Vernuccio, M. (2004). Marketing, innovazione e tecnologie digitali: una lettura in ottica sistemica. Cedam.

Paul, J., \& Rana, J. (2012). Consumer behaviour and purchase intention for organic food. Journal of consumer Marketing, 29(6), 412-422.

Poirier, J., Clapier-Valladon, S., \& Raybaut, P. (1983). Les récits de vie: théorie et pratique (Vol. 52). Presses universitaires de France.

Prandelli, E., \& Verona, G. (2002). Marketing in Rete. Analisi e decisioni nell'economia digitale. McGraw-Hill.

Puccinelli, N. M., Goodstein, R. C., Grewal, D., Price, R., Raghubir, P., \& Stewart, D., Customer experience management in retailing: understanding the buying process, Journal of retailing, 85(1), 2009, pp. 15-30.

Quester, P., Neal, C., Pettigrew, S., Grimmer, M. R., Davis, T., \& Hawkins, D. (2007). Consumer behaviour: Implications for marketing strategy. McGraw-Hill.

Raimondi M., Marketing del prodotto-servizio. Integrare tangibile e intangibile per offrire valore al cliente, 2005, p. 182 e p. 242.

Raymond A. Bauer, Consumer Behaviour as Risk Taking, in Dynamic Marketing for a Changing World, 1960, pp. 389398.

Richins, M. L., Measuring emotions in the consumption experience, Journal of consumer research, 24(2), 1997, pp. 127146.

Ryan, D. (2016). Understanding digital marketing: marketing strategies for engaging the digital generation. Kogan Page Publishers.

Roger A. Kerin, Steven W. Hartley, W. Rudelius, L. Pellegrini, Marketing, 9 editions, 2010, pp. 139-150 e pp. $443-448$.

Rom J. Markin, The Psychology of Consumer Behaviour, Englewood Cliffs, N. J.: Prentice-Hall, 1969.

Sassatelli, R. (2004). Consumo, cultura e società. Il mulino.

Schiffman, L., O'Cass, A., Paladino, A., \& Carlson, J. (2013). Consumer behaviour. Pearson Higher Education AU.

Sherman, E., Mathur, A., \& Smith, R. B. (1997). Store environment and consumer purchase behaviour: mediating role of consumer emotions. Psychology and Marketing, 14(4), 361-378.

Sheth, J. N., \& Venkatesan, M. (1968). Risk-reduction processes in repetitive consumer behaviour. Journal of Marketing Research, 307-310.

Silverman, D. (2013). Doing qualitative research: A practical handbook. SAGE Publications Limited.

Sicca, L. (2000). La gestione strategica dell'impresa. Cedam.

Sirgy, M. J. (1982). Self-concept in consumer behaviour: A critical review. Journal of consumer research, 9(3), 287-300.

Symon, G. (1998). Qualitative research diaries. Sage Publications Ltd.

Solomon, M. R. (2014). Consumer behaviour: Buying, having, and being (Vol. 10). Upper Saddle River, NJ: Prentice Hall.

Stemler, S. (2001). An overview of content analysis. Practical assessment, research \& evaluation, 7(17), $137-146$.

Taylor, J. W. (1974). The role of risk in consumer behaviour. The Journal of Marketing, 54-60.

Tippins, M. J., Rassuli, K. M., \& Hollander, S. C. (2002). An assessment of direct farm-to-table food marketing in the USA. International Journal of Retail E Distribution Management, 30(7), 343-353.

Timmermans, S., \& Tavory, I. (2012). Theory construction in qualitative research: From grounded theory to abductive analysis. Sociological Theory, 30(3), 167-186.

Wang, R. J. H., Malthouse, E. C., \& Krishnamurthi, L. (2015). On the go: How mobile shopping affects customer purchase behaviour. Journal of Retailing, 91(2), 217-234.

Wiedermann, B., \& Cook, W. R. (2007, January). Extracting queries by static analysis of transparent persistence. In ACM SIGPLAN Notices (Vol. 42, No. 1, pp. 199-210). ACM.

Wiersma, W. 1986. Research Methods in Education: An Introduction. Newton: Allyn and Bacon.

Wind, J., \& Rangaswamy, A. (2001). Customerization: The next revolution in mass customization. Journal of interactive marketing, 15(1), 13-32.

Urban, G. (2003). Digital marketing strategy: text and cases. Prentice-Hall, Inc.

Venkatesan, M. (1966). Experimental study of consumer behaviour conformity and independence. Journal of Marketing Research, 384-387.

Verhoef, P. C., Kannan, P. K., \& Inman, J. J. (2015). From multi-channel retailing to omni-channel retailing: introduction to the special issue on multi-channel retailing. Journal of retailing, 91(2), 174-181.

Vicari, S. (2001). Il management nell'era della connessione. Egea.

Zabieglik S., The origins of the term homo oeconomicus, Economics and values, 2002, pp. 123-131.

Zaichkowsky J. L., Measuring the involvement construct, Journal of consumer research, 1985, p. 341.

Zeugner-Roth, K. P., Žabkar, V., \& Diamantopoulos, A. (2015). Consumer ethnocentrism, national identity, and consumer cosmopolitanism as drivers of consumer behaviour: A social identity theory perspective. Journal of international marketing, 23(2), 25-54. 
Zhang, Y. (2015). The impact of brand image on consumer behaviour: a literature review. Open journal of business and management, 3(1).

Zineldin M., \& Philipson S., Kotler and Borden are not dead: myth of relationship marketing and truth of the 4Ps. Journal of consumer marketing, 2007, pp. 229-241.

Zimmerman, D. H., \& Wieder, D. L. (1977). The diary: diary-interview method. Urban life, 5(4), 479-498.

Appendix: The Diary of Consumer

UnIVERSITÁäLuSTUDI di Napol Federico II

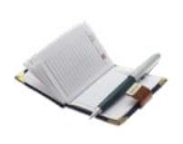

\section{Diario del consumatore}

L'obiettivo di questo lavoro di ricerca è di indagare attraverso un "diario" il comportamento del Responsabile di Acquisto di nuclei familiari ubicati nell'area metropolitana di Napoli e provincia, relativamente alle categorie di prodotto alimentari, detergenti e cura per il corpo. La ricerca è di natura accademica ed è finalizzata ad una pubblicazione scientifica. Essa è condotta da ricercatori del Laboratorio di Marketing, sotto il Coordinamento del Prof. Luigi Cantone, Ordinario di Marketing e Strategie d'Impresa, Dipartimento, Economia, Management, Istituzioni - Università degli Studi di Napoli Federico II. Le informazioni desunte dalla ricerca saranno elaborate anche per la redazione delle tesi di laurea degli studenti Gennaro Aquino e Alessandro Pellegrino. Il "diario" ha una struttura guidata e si compone di quattro aree informative che descrivono l'attività di acquisto giornaliera del Responsabile di Acquisto. A termine di ciascuna giornata il Responsabile di Acquisto, lungo un periodo di osservazione di 30 giorni, dovrà compilare il "diario" fornendo le indicazioni richieste negli specifici campi informativi. In alcuni punti (1, 3 e 4) del "diario", il rispondente dovrà barrare specificando i campi presenti.

\section{1- Dove ha comprato, in quale negozio? (Tabella 1)}

Il rispondente dovrà indicare la tipologia di negozio nel quale ha effettuato gli acquisti del giorno. Più in dettaglio, dovrà indicare se ha effettuato acquisti in piccole superfici specializzate tradizionali (es. macelleria, fruttivendolo), e/o superfici di vendita senza struttura fisica fissa (es. mercati rionali, vendita ambulante), e/o grandi strutture della distribuzione moderna (es. Conad, Carrefour, Auchan), e/o piattaforme di vendita on-line (es. Amazon, Etaly, etc.), e/o vendita presso superfici specializzate nel biologico (Naturasi, Nambio, etc.) e/o a km O (GAS - Gruppi di Acquisto Solidale).

\section{2- Perché ha comprato in quel negozio quei prodotti? (Tabella 2 e 4)}

Quali sono le motivazioni che hanno determinato il comportamento di acquisto del/della responsabile (fiducia e/o empatia nel personale di vendita, e/o convenienza, e/o livello di servizio, e/o qualità dei prodotti, e/o prossimità del p.d.v., e/o fiducia nella marca dell'insegna, e/o programmi fedeltà, etc.). A solo titolo di esempio, il rispondente che abbia acquistato della carne in un supermercato, dovrebbe motivare perché ha fatto ricorso a quella tipologia di format in luogo di altre forme distributive alternative per la specifica categoria di prodotto (nel caso della carne, la macelleria e/o il mercato rionale, etc.)

\section{3- Quali categorie di prodotti ha acquistato? (Tabella 3)}

Il/la responsabile di acquisto dovrebbe indicarci quale tipologia di prodotti ha acquistato in ciascun dei format distributivi indicati al punto 1.

\section{4- Che cosa ha imparato oggi nel fare gli acquisti? (Tabella 5)}

Il/la responsabile di acquisto dovrebbe riflettere sulla esperienza di acquisto delle giornate ed indicare se ci sono delle osservazioni, suggerimenti, consigli che discendono da esigenze che non hanno avuto adeguato riscontro nell'offerta degli operatori della distribuzione (tradizionale e/o moderna) con cui è entrato/a in contatto. 
Data e ora:

..................................

1- Dove ha comprato, in quale negozio? (barrare con una o più $\mathrm{x} \mathrm{e} / \mathrm{o}$ indicare)

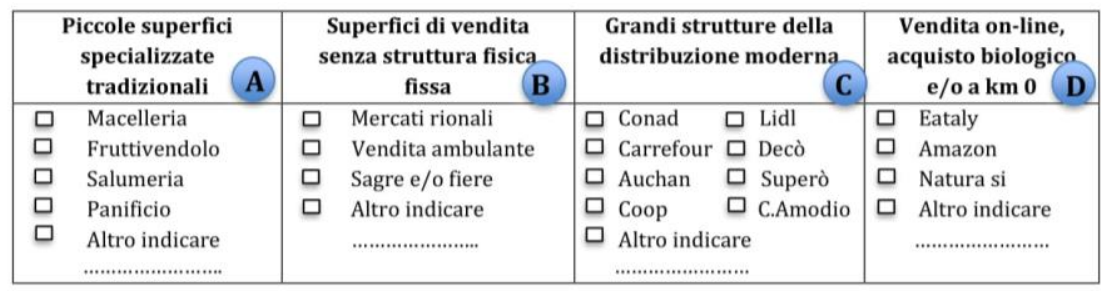

2- Perché ha comprato in quel negozio?

A

B

C.

D

3- Quali categorie di prodotti ha acquistato? (barrare con una o più x e/o indicare)

\begin{tabular}{|c|l|l|}
\hline \multicolumn{2}{|c|}{ Prodotti freschi da banco } & \multicolumn{2}{|c|}{$\begin{array}{c}\text { Scatolame ed altri prodotti } \\
\text { da scaffale }\end{array}$} & F & \\
\hline$\square$ Carne & $\square$ Pasta & $\square$ Dentifrici \\
$\square$ Pesce & $\square$ Sughi & $\square$ Pulizia per la casa \\
$\square$ Frutta & $\square$ Legumi & $\square$ Pulizia e cura della persona \\
$\square$ Verdura & $\square$ Biscotti & $\square$ Altro indicare \\
$\square$ Altro indicare & $\square$ Altro indicare & \\
\hline
\end{tabular}

4- Perché ha comprato quei prodotti nei negozi innanzi indicati? (barrare con una o più $\mathrm{x}$ )

$\mathrm{A}$ E $\mathrm{G}$

B E $\mathrm{F}$ G

CE!G

DE

5- Che cosa ha imparato oggi nel fare gli acquisti? 